\title{
A POLISH ADAPTATION AND VALIDATION OF THE YALE FoOd AdDiction SCALE 2.0 POLSKA ADAPTACJA I WALIDACJA YALE FOOD ADDICTION SCALE 2.0
}

\author{
Ryszard Wojciech Poprawa $^{1}$ ID , Bianka Lewandowska1 ${ }^{1}$, Małgorzata Włodarczyk ${ }^{1}$ ID, Katarzyna Tutka ${ }^{2}$ \\ ${ }^{1}$ Institute of Psychology, University of Wrocław, Poland \\ ${ }^{2}$ Therapy Center "Promena", Wrocław, Poland \\ ${ }^{1}$ Instytut Psychologii, Uniwersytet Wrocławski, Polska \\ ${ }^{2}$ Ośrodek Terapeutyczny „Promena”, Wrocław, Polska
}

Alcohol Drug Addict 2020; 33 (4): 283-312

DOI: https://doi.org/10.5114/ain.2020.104814

\begin{abstract}
Introduction: Food addiction is defined by a pattern of eating high-calorie foods, which is similar to psychoactive substance dependence. The aim of the study was to validate the Polish adaptation of the Yale Food Addiction Scale 2.0 (YFAS 2.0), which measures the degree of food addiction based on 11 addiction criteria according to DSM-5.

Material and methods: Validation studies were carried out on a sample of 431 people $(67.75 \%$ women), aged 18-60. Construct validity was assessed using CFA (confirmatory factor analysis) for dichotomous diagnostic data. Reliability was assessed by analysing time stability of the results, internal consistency and item-total correlations. Validity was assessed using body weight, BMI, Scale of Involvement on Eating
\end{abstract}

\begin{abstract}
Streszczenie
Wprowadzenie: Uzależnieniem od jedzenia określa się wzorzec jedzenia wysokokalorycznych pokarmów, który w swoim obrazie i konsekwencjach przypomina uzależnienie od substancji psychoaktywnych. Celem badania była walidacja polskiej adaptacji Yale Food Addiction Scale 2.0 (YFAS 2.0), mierzącej stopień uzależnienia od jedzenia na podstawie 11 kryteriów uzależnień wg DSM-5.

Materiał i metody: Po uzyskaniu równoważnego polskiego tłumaczenia przeprowadzono badania walidacyjne na próbie 431 osób (67,75\% kobiet), w wieku od 18 do 60 lat. Trafność teoretyczną oceniono z użyciem CFA (konfirmacyjnej analizy czynnikowej) dla dychotomicznych danych diagnostycznych. Rzetelność oceniono, analizując stałość czasową wyników, spójność wewnętrzną i moc dyskryminacyjną pozycji. Trafność oceniano za pomocą masy ciała,
\end{abstract}

Correspondence to/Adres do korespondencji: Ryszard Wojciech Poprawa, Instytut Psychologii, Uniwersytet Wrocławski, ul. Dawida 1, 50-527 Wrocław, Polska, phone: +48 71367 2001, ext. 121, e-mail: ryszard.poprawa@uwr.edu.pl

Authors' contribution/Wkład pracy autorów: Study design/Koncepcja badania: R.W. Poprawa, K. Tutka; Data collection/Zebranie danych: R.W. Poprawa, B. Lewandowska, K. Tutka, M. Włodarczyk; Statistical analysis/Analiza statystyczna: R.W. Poprawa; Data interpretation/ Interpretacja danych: R.W. Poprawa, B. Lewandowska, K. Tutka; Acceptance of final manuscript version/Akceptacja ostatecznej wersji pracy: R.W. Poprawa, B. Lewandowska, M. Włodarczyk; Literature search/Przygotowanie literatury: R.W. Poprawa, B. Lewandowska, K. Tutka, M. Włodarczyk

No ghostwriting and guest authorship declared./Nie występują zjawiska ghostwriting i guest authorship.

Submitted/Otrzymano: 28.11.2019 • Accepted/Przyjęto do druku: 10.07.2020

(c) 2020 Institute of Psychiatry and Neurology. Production and hosting by Termedia sp. z o.o.

This is an open access article under the CC BY-NC-ND license (http://creativecommons.org/licenses/by-nc-nd/4.0/) 
Behaviour (SZJ), Three Factor Eating Questionnaire and Self-Control Scale. Differences in selected reliability indicators depending on the YFAS 2.0 diagnostic grades were analysed. The severity of symptoms was compared between food addicts anonymous, individuals enrolled in a weight-loss programme and those from a normative sample.

Results: CFA demonstrated a perfect fit between the study results and the theoretical model of the YFAS 2.0. High coefficients of reliability measures were obtained. The YFAS 2.0 positively correlates with body weight, BMI, SZJ results, difficulties in controlling eating and emotional eating, and negatively with self-control ability. Significant differences were found in the validity indicators and between compared groups, depending on the diagnostic degrees of food addiction.

Discussion: The Polish adaptation of YFAS 2.0 is characterised by high reliability and validity.

Conclusions: The Polish adaptation of YFAS 2.0 has very good psychometric properties and can be used in scientific research and clinical practice.

Keywords: Food addiction, YFAS 2.0, Polish adaptation, Validation.
BMI, Skali Zaabsorbowania Jedzeniem (SZJ), Three Factor Eating Questionnaire oraz Self-Control Scale. Analizowano różnice $\mathrm{w}$ wybranych wskaźnikach rzetelności zależne od stopni diagnostycznych YFAS 2.0. Porównano nasilenie objawów między osobami uzależnionymi od jedzenia, osobami odchudzającymi się i osobami z próby normatywnej.

Wyniki: CFA wykazała doskonałe dopasowanie wyników badań do modelu teoretycznego YFAS 2.0. Uzyskano dostateczne i wysokie współczynniki miar rzetelności. Stwierdzono pozytywne korelacje YFAS $2.0 \mathrm{z}$ masą ciała, BMI, wynikami SZJ, trudnościami w kontroli jedzenia i jedzeniem o podłożu emocjonalnym, a negatywne ze zdolnością do samokontroli. Wykazano istotne różnice w przyjętych wskaźnikach trafności oraz między porównywanymi grupami zależne od diagnostycznych stopni uzależnienia od jedzenia.

Omówienie: Polska adaptacja YFAS 2.0 charakteryzuje się wysoką rzetelnością oraz trafnością.

Wnioski: Polska adaptacja YFAS 2.0 ma bardzo dobre właściwości psychometryczne i może być wykorzystana w badaniach naukowych i w praktyce.

Słowa kluczowe: uzależnienie od jedzenia, YFAS 2.0, polska adaptacja, walidacja.

\section{- INTRODUCTION}

The concept of compulsive overeating or food addiction is applied to describe the tendency of some individuals to eat certain types of food both in terms of behaviour and consequences similar to psychoactive substance use. What is consumed is primarily calorie rich, highly processed food with high concentrations of fat or refined sugar (e.g., chips, sweets, fizzy drinks), with an evolutionarily conditioned potential to activate the reward system and elevate $\operatorname{mood}[1,2]$.

Currently, food addiction is not considered as a separate nosological entity, only having the status of a syndrome observed in clinical practice. Nor is it mentioned in any of the international classifications of mental disorders $[3,4]$, and thus there are no official psychiatric criteria for diagnosing this problem or assessing its severity. At the same time, in the course of

\section{WPROWADZENIE}

Pojęcie napadowego objadania się czy też uzależnienia od jedzenia jest używane w celu określenia występującej u niektórych jednostek tendencji do jedzenia pewnych rodzajów żywności w sposób i z konsekwencjami przypominającymi używanie substancji psychoaktywnych. Chodzi tu przede wszystkim o żywność wysokokaloryczną, znacznie przetworzoną, zawierającą wysokie stężenie tłuszczu lub cukru rafinowanego (np. chipsy, słodycze, napoje gazowane), mającą ewolucyjnie uwarunkowany potencjał aktywowania układu nagrody i poprawy nastroju $[1,2]$.

Obecnie uzależnienie od jedzenia nie jest uznawane za odrębną jednostkę chorobową, ma jedynie status syndromu obserwowanego w praktyce klinicznej. Nie jest też wymieniane w żadnej z międzynarodowych klasyfikacji zaburzeń zdrowia psychicznego $[3,4]$, a tym samym nie istnieją oficjalne kryteria psychiatryczne służące do diagnozy tego problemu lub oceny jego nasilenia. Jednocześnie $\mathrm{w}$ przebiegu wybranych zaburzeń odżywiania można zaobserwować wzorce zacho- 
selected eating disorders behavioural patterns characteristic of addiction may be observed, like compulsive consumption of large amounts of food despite attempts at restriction or repeated experience of loss of control during consumption of certain types of food [3-6].

The increased interest in the concept of food addiction is associated with the pandemic spread of obesity and, at the same time, the discovery, by means of neuroimaging techniques, of similarities in brain function of the overeating obese persons, those with selected eating disorders and people suffering from psychoactive substance use disorders and behavioural addictions $[7,8]$. Since the same psychological and biological mechanisms have been observed in addictive behaviour and in certain forms of overeating, this problem has been the focus of intense scientific debate $[9$, 10]. The addictive potential of selected nutrients, similarity of certain overeating behaviours to patterns observed in dependences, neurophysiological mechanisms of reaction to certain foods and addictive eating behaviours are studied [11-13]. As addictive potential is demonstrated with respect to individual nutrients rather than specific foods, some researchers postulate that this disorder be described as eating addiction rather than food addiction [10].

Should food addiction be considered as a distinct, specific disorder, and if so, what is the prevalence of this problem and can the neurophysiological, behavioural and cognitive mechanisms that underlie other types of addiction (e.g., substantial) be distinguished in those affected? In order to seek answers to these questions, it was necessary to develop a reliable research tool. In 2009 Gearhardt and colleagues constructed the Yale Food Addiction Scale (YFAS) [14]. This tool was based on the DSM-IV-TR substance dependence criteria [15]. The DSM-5 [3], introduced in 2013, reformulated the definition and selected criteria of dependence (combining the symptoms of abuse and dependence, removing the legal criterion, adding substance craving and specifying the criteria for severity of the disorder), while combining substantial dependence and behavioural addiction, so YFAS also required modification. In 2016, a version of YFAS 2.0 based on DSM- 5 addictive behaviour criteria wań charakterystyczne dla uzależnienia, takie jak kompulsywne spożywanie dużych ilości jedzenia, mimo podejmowanych prób ograniczenia, czy powtarzające się doświadczenie utraty kontroli podczas jedzenia pewnych typów pokarmów [3-6].

Wzrost zainteresowania koncepcją uzależnienia od jedzenia wiąże się z pandemicznym rozprzestrzenianiem się otyłości i jednocześnie z odkrywaniem, za pomocą technik neuroobrazowania, podobieństw $\mathrm{w}$ funkcjonowaniu mózgu przejadających się osób otyłych, osób z wybranymi zaburzeniami odżywiania oraz osób cierpiących z powodu zaburzeń związanych $\mathrm{z}$ używaniem substancji psychoaktywnych i uzależnień behawioralnych $[7,8]$. Od momentu, w którym zauważono występowanie tych samych mechanizmów psychologicznych i biologicznych w zachowaniach nałogowych oraz w pewnych postaciach przejadania się, problem ten jest przedmiotem intensywnej debaty naukowej $[9,10]$. Badaniami objęto uzależniający potencjał wybranych składników pokarmowych, podobieństwo pewnych zachowań związanych $\mathrm{z}$ objadaniem się ze wzorami obserwowanymi $\mathrm{w}$ uzależnieniach, neurofizjologiczne mechanizmy reakcji na pewne pokarmy i nałogowe zachowania jedzeniowe [11-13]. Ze względu na to, że uzależniający potencjał ujawnia się raczej w odniesieniu do poszczególnych składników odżywczych niż konkretnych produktów żywnościowych, niektórzy badacze postulują, by to zaburzenie określić jako uzależnienie od jedzenia (eating addiction), a nie uzależnienie od żywności (food addiction) [10].

Czy uzależnienie od jedzenia należy ujmować jako odrębne, specyficzne zaburzenie, a jeśli tak, to jakie jest rozpowszechnienie tego problemu? A także czy u osób nim dotkniętych można wyróżnić mechanizmy neurofizjologiczne, behawioralne i poznawcze, które leżą u podstaw innych uzależnień, np. substancjalnych? Aby szukać odpowiedzi na te pytania, potrzebne było opracowanie rzetelnego narzędzia badawczego. W 2009 r. Gearhardt i wsp. skonstruowali Yale Food Addiction Scale (YFAS) [14]. Autorzy posłużyli się kryteriami uzależnienia zamieszczonymi w DSM-IV-TR [15]. We wprowadzonym w 2013 r. DSM-5 [3] przeformułowano definicję i wybrane kryteria uzależnienia (połączono objawy nadużywania i uzależnienia, usunięto kryterium prawne, dodano głód substancji oraz określono kryteria nasilenia zaburzenia), jednocześnie łącząc uzależnienia substancjalne $\mathrm{z}$ behawioralnymi. W związku $\mathrm{z}$ tym zmodyfikowania wymagała również YFAS. W 2016 r. na podstawie kryteriów zachowań nałogowych z DSM-5 powstała wersja YFAS $2.0[16,17]$, a rok później także jej skrócona wersja [18]. Umożliwiło to po- 
was developed [16, 17] followed by a shortened version one year later [18]. This made it possible to measure the severity of food addiction in the general population and in selected clinical groups, initially in the USA and later, thanks to subsequent adaptations, also in other countries $[6,19-22]$.

This tool measures 11 symptoms of food addiction, i.e. 1) substance taken in larger amount and for longer period than intended, 2) persistent desire or repeated unsuccessful attempts to quit, 3) much time/activity to obtain, use, recover, 4) important social, occupational or recreational activities given up or reduced, 5) use continues despite knowledge of adverse consequences, 6) tolerance (marked increase in amount, marked decrease in effect), 7) characteristic withdrawal symptoms, substance taken to relieve withdrawal, 8) continued use despite social or interpersonal problems, 9) failure to fulfil major role obligations (e.g. work, school, home), 10) use in physically hazardous situations, 11) craving or a strong desire or urge to use. These symptoms have been accompanied as a necessary clinical diagnostic criterion and 12) impairment or distress. Food addiction may be inferred, according to the criteria adopted by YFAS 2.0 authors, if this problematic eating pattern leads to significant clinical problems and excessive stress providing the symptoms occurred within the last 12 months $[16,18]$.

Studies to date have shown that the prevalence of food addiction ranges from $8.2 \%$ to as much as $47.4 \%$ depending on the type and characteristics of the sample [23, 24]. Significant relationships between food addiction and selected disorders such as compulsive overeating $[25,26]$, bulimia $[27,28]$, disorders of emotional regulation or selected mood disorders [29] as well as somatic problems like obesity, cyclic weight fluctuations or type II diabetes $[23,30]$ have been revealed.

\section{Study aim}

It is estimated that about $50 \%$ of adults are overweight and 16-20\% are obese [31] in Poland. As the problem of obesity and various eating disorders increases, there is a growing need to understand the underlying mechanisms including the role of the addictive eating behaviour patterns miar nasilenia uzależnienia od jedzenia w populacji ogólnej oraz w wybranych grupach klinicznych, początkowo w USA, a potem - dzięki kolejnym adaptacjom - także w innych krajach [6, 19-22].

Narzędzie to mierzy 11 objawów uzależnienia od jedzenia: 1) przyjmowanie większych ilości określonych pokarmów i w czasie dłuższym niż planowano, 2) nieustające pożądanie określonego jedzenia lub jego ograniczanie, kontrolowanie kończące się niepowodzeniem, 3) spędzanie dużych ilości czasu na czynnościach, których celem jest znalezienie określonego pożywienia, jedzenie go oraz redukowanie negatywnych tego konsekwencji, 4) zaniedbywanie lub porzucanie z powodu jedzenia ważnych życiowych aktywności, 5) powtarzające się przyjmowanie nadmiernych ilości określonego jedzenia pomimo świadomości negatywnych tego konsekwencji, 6) tolerancja wyrażająca się wyraźnym zwiększeniem ilości określonego jedzenia i postępującym spadkiem pożądanego efektu, 7) pojawianie się charakterystycznych, negatywnych symptomów odstawiennych (po ograniczeniu lub zaprzestaniu jedzenia niektórych pokarmów) i powracanie do nadmiernego jedzenia w celu redukcji tych objawów, 8) kontynuowanie przejadania się pomimo powracających problemów społecznych, w tym interpersonalnych, 9) przejadanie się, które przyczynia się do niewypełniania ról społecznych (w pracy, domu czy szkole), 10) jedzenie pewnych produktów nawet w przypadku zagrożenia zdrowia i życia, 11) pożądanie lub silna potrzeba zjedzenia pewnych produktów, której trudno się oprzeć. Do wymienionych objawów dołączono jako konieczne kliniczne kryterium diagnostyczne: 12) wystąpienie dystresu i problemów życiowych spowodowanych przez sposób odżywania się. O uzależnieniu od jedzenia można wnioskować (wg przyjętych przez autorów YFAS 2.0 kryteriów), jeśli ten problemowy wzorzec odżywiania się prowadzi do znaczących problemów klinicznych i nadmiernego stresu, przy czym objawy muszą wystąpić w ciągu ostatnich 12 miesięcy $[16,18]$.

W dotychczasowych badaniach stwierdzono, że rozpowszechnienie uzależnienia od jedzenia waha się od $8,2 \%$ aż do $47,4 \% \mathrm{w}$ zależności od rodzaju i charakterystyki badanej próby $[23,24]$. Wykazano istotne związki uzależnienia od jedzenia $\mathrm{z}$ wybranymi zaburzeniami, takimi jak napadowe objadanie się $[25,26]$, bulimia $[27,28]$, zaburzenia regulacji emocji czy wybrane zaburzenia nastroju [29], a także z problemami somatycznymi, np. otyłością, cyklicznymi wahaniami masy ciała czy cukrzycą typu $2[23,30]$.

\section{Cel badań}

Szacuje się, że w Polsce ok. 50\% osób dorosłych ma nadmierną masę ciała, a $16-20 \%$ jest otyłych 
described above. The need for accurate diagnosis is also growing in clinical practice as there is data indicating the effectiveness of undertaking therapeutic interventions developed in the treatment of dependence in relation to such problematic patterns of behaviour [32-34]. The aim of this work is to present the results of research on Polish adaptation and validation of YFAS 2.0.

\section{Hypotheses}

The basis for assessing the value of each tool is to confirm its construct validity. Its confirmation is of cardinal importance for the assessment of the tool's value and includes various aspects or research methods, often referred to as types of validity [35]. In order to confirm the validity of the Polish version of YFAS 2.0, in accordance with textbook standards [35], several hypotheses were presented and many methods for their verification were adopted.

- Hypothesis 1 (H1). If YFAS 2.0, as assumed by the authors [16], measures 11 symptoms of food addiction according to DSM-5 criteria, it should be confirmed by confirmatory factor analysis (CFA) carried out on dichotomous diagnostic data.

- Hypothesis 2 (H2). The overall YFAS 2.0 score as well as in individual subscales (symptoms) correlates positively with: (H2.1) body weight; (H2.2) body mass index (BMI); (H2.3) absorption of food and its undersized dimensions, i.e. a) involvement and focus on food, b) using food to make oneself feel better and more pleasant and to improve one's mood and c) compulsion and loss of control over eating [36]; (H2.4) eating related problems, i.e. a) difficulty in controlling eating, b) limiting eating in order to control weight and body image and c) emotional eating (associated with low mood and anxiety) [37]. Positive verification of this hypothesis will confirm the tool's convergent validity.

- Hypothesis 3 (H3). The overall YFAS 2.0 score and its individual subscales correlated negatively with self-control ability [38]. Positive verification of this hypothesis will confirm the tool's discriminant validity.
[31]. Wraz $z$ nasilaniem się problemu otyłości i rozmaitych zaburzeń odżywiania się narasta potrzeba zrozumienia mechanizmów leżących u ich podłoża, w tym roli opisanych wyżej nałogowych wzorów zachowań związanych $\mathrm{z}$ jedzeniem. Potrzeba ich dokładnego diagnozowania odnosi się także do praktyki klinicznej, istnieją bowiem dane, które wskazują na efektywność podejmowania wobec takich problemowych wzorów zachowań interwencji terapeutycznych wypracowanych w leczeniu uzależnień [32-34]. Celem niniejszej pracy jest zaprezentowanie wyników badań nad polską adaptacją i walidacją YFAS 2.0.

\section{Hipotezy}

Podstawą oceny wartości każdego narzędzia jest potwierdzenie jego trafności teoretycznej. Ma to kardynalne znaczenia dla oceny wartości narzędzia i obejmuje różne aspekty czy też metody badawcze, często określane jako rodzaje trafności [35]. W celu potwierdzenia trafności polskiej wersji YFAS 2.0, zgodnie z podręcznikowymi standardami [35], postawiono szereg hipotez i przyjęto wiele metod ich weryfikacji.

- Hipoteza 1 (H1). Jeśli YFAS 2.0, zgodnie z założeniami autorów [16], mierzy 11 objawów uzależnienia od jedzenia według kryteriów DSM-5, powinna to potwierdzić konfirmacyjna analiza czynnikowa (CFA) przeprowadzona na dychotomicznych danych diagnostycznych.

- Hipoteza 2 (H2). Zarówno wynik ogólny YFAS 2.0, jak i w poszczególnych podskalach (objawach) koreluje pozytywnie z (H2.1) masą ciała; (H2.2) indeksem masy ciała (BMI); (H2.3) zaabsorbowaniem jedzeniem i jego podwymiarami, tj. a) zaangażowaniem i koncentracją na jedzeniu, b) wykorzystywaniem jedzenia do sprawienia sobie przyjemności i poprawienia nastroju, c) przymusem jedzenia i utratą nad nim kontroli [36]; (H2.4) problemami związanymi ze sposobem odżywiania się, tj. a) trudnościami $\mathrm{z}$ kontrolą jedzenia, b) ograniczaniem jedzenia w celu kontrolowania masy i wizerunku ciała, c) jedzeniem na podłożu emocjonalnym (powiązanym $\mathrm{z}$ obniżonym nastrojem i zaniepokojeniem) [37]. Pozytywna weryfikacja tej hipotezy potwierdzałaby trafność zbieżną narzędzia.

- Hipoteza 3 (H3). Wynik ogólny YFAS 2.0 i jej poszczególne podskale korelują negatywnie ze zdolnością do samokontroli [38]. Pozytywna weryfikacja tej hipotezy potwierdzałaby trafność różnicową narzędzia. 
- Hypothesis 4 (H4). Diagnostic results of YFAS 2.0 (were included in the severity of symptoms of food addiction, i.e., 0 - no symptoms, 1 - mild, 2 - moderate, 3 - severe) differentiate significantly in terms of 1) body weight, 2) intensity of involvement on food (SZJ) and its sub-indices, 3) difficulty with food control, 4) emotional eating and 5) ability to self-control. In other words, it has been assumed that if YFAS 2.0 correctly recognises food addiction, people with high intensity of symptoms should have significantly higher scores in the first four variables analysed, and lower self-control scores than those with no or only mild symptoms.

- Hypothesis 5 (H5). Members of the support group for food addicts (so-called Food Addicts Anonymous - FAA) and participants of the weight-loss and fitness programme would score higher in YFAS 2.0 than those from the normative sample. Positive verification of two last hypotheses will confirm the tool's diagnostic validity.

\section{- MATERIAL AND METHOdS}

\section{Respondents}

Data was collected from a total of 431 subjects from different regions of Poland, aged 18 to 60 $(\mathrm{M}=32.65, \mathrm{SD}=12.96)$ between May and October 2018 . Women made up $67.75 \%$ of the sample. Five respondents did not provide gender information. Respondents had mostly secondary (52.2\%) and higher education (26.54\%), plus undergraduate or engineering (14.15\%) and basic vocational (2.78\%) and primary (1.16\%). Five persons did not provide information about their education. Three groups can be distinguished in the sample: 1) normative ( $92.11 \%$ of the sample), 2) 25 food addicts anonymous, recruited during an annual national meeting and 3) 9 participants of a sanatorium weight-loss programme.

The BMI of the subjects was determined based on body weight, height and gender as $7.58 \%$ underweight, $54.27 \%$ normal, $22.75 \%$ overweight, $11.61 \%$ obese and $3.79 \%$ clinically obese.

\section{Procedure}

This was a three-stage study. In the first stage, the team worked on a Polish translation
- Hipoteza 4 (H4). Diagnostyczne wyniki YFAS 2.0 (ujęte w stopnie nasilenia objawów uzależnienia od jedzenia, tj. 0 - bez objawów, 1 - w stopniu lekkim, 2 - umiarkowanym, 3 - ciężkim) istotnie różnicują pod względem: 1) masy ciała, 2) nasilenia zaabsorbowania jedzeniem (SZJ) i jego wskaźników cząstkowych, 3) trudności z kontrolą jedzenia, 4) jedzenia na podłożu emocjonalnym oraz 5) zdolności do samokontroli. Inaczej mówiąc, założono, że jeśli YFAS 2.0 trafnie rozpoznaje uzależnienie od jedzenia, to osoby o wysokim stopniu nasilenia objawów powinny uzyskiwać istotnie wyższe wyniki w czterech pierwszych analizowanych zmiennych, a niższe w zakresie samokontroli niż osoby niemające objawów lub mające je w stopniu lekkim.

- Hipoteza 5 (H5). Osoby należące do grupy wsparcia dla uzależnionych od jedzenia (FAA) oraz uczestnicy programu odchudzająco-kondycyjnego uzyskają wyższe wyniki w YFAS 2.0 niż osoby z próby normatywnej. Pozytywna weryfikacja tych dwóch ostatnich hipotez potwierdzałaby trafność diagnostyczną narzędzia.

\section{- MATERIAt I METOdY}

\section{Badani}

W okresie od maja do października 2018 r. łącznie zebrano dane od 431 osób, mieszkańców różnych regionów Polski, $w$ wieku od 18 do 60 lat $(\mathrm{M}=32,65$, $\mathrm{SD}=12,96)$. Kobiety stanowily $67,75 \%$ próby. Pięć osób nie podało informacji o płci. Większość badanych miała wykształcenie średnie $(52,2 \%)$ i wyższe magisterskie $(26,54 \%)$, ponadto licencjackie lub inżynierskie $(14,15 \%)$ oraz zasadnicze zawodowe $(2,78 \%)$ i podstawowe $(1,16 \%)$. Pięć osób nie podało informacji o swoim wykształceniu. W próbie można wyróżnić trzy grupy: 1) normatywną (92,11\% próby), 2) 25 osób uzależnionych od jedzenia zrekrutowanych podczas dorocznego ogólnokrajowego mitingu oraz 3) 9 uczestników sanatoryjnego programu odchudzająco-kondycyjnego.

Na podstawie masy ciała, wzrostu i płci określono BMI badanych: 7,58\% miało niedowagę, 54,27\% mieściło się $\mathrm{w}$ normie, $22,75 \%$ miało nadwagę, $11,61 \%$ było otyłych, a 3,79\% klinicznie otyłych.

\section{Procedura}

Badanie było trzyetapowe. Na pierwszym etapie zespołowo przygotowano polskie tłumaczenie 
of YFAS 2.0, which was then subjected to a linguistic equivalence test using the bilingual responses method on a sample of 18 final-year English philology students [39]. Half of the respondents were given the Polish and the other half the English version of the tool to complete. After two weeks, the study was repeated by applying a different YFAS 2.0 language version. The obtained results were discussed by the team and modifications were made to the translation of several statements, maintaining their content validity, in accordance with the DSM-5 addiction criteria [3] and the YFAS 2.0 response key $[40,41]$.

The second stage of research started using this revised questionnaire version. The original YFAS 2.0 items and the Polish language versions are presented in Annex. In this stage, 76 psychology of eating-disorder course students were subjected to a group test-retest examination, with an interval of three weeks between tests. The aim of this study was to determine the absolute time stability of results [35]. Fifty students took part in the retest. After completing their own participation in the study, selected students were invited to cooperate in data collection and trained accordingly.

In the third stage, the research was carried out individually. At the beginning, all students were briefly informed about the purpose of the study, its course and form, voluntary participation, anonymity and confidentiality of information provided. After agreeing to participate, respondents were asked to provide basic demographic data, weight and height. All validation questionnaires were then included with standard instructions for YFAS 2.0, SZJ, SCS and TFEQ-13.

\section{Tools}

Yale Food Addiction Scale 2.0 (YFAS 2.0) by Gearhardt, Corbin \& Brownell [16] (see Annex) is used to assess the incidence of eating-related addictive behaviour in the last 12 months. The scale consists of 35 items that the person assesses on an 8-point response scale, ranging from 0 "never" to 7 "daily". Two items (16 and 17, see Annex) refer to a clinically significant impairment or suffering resulting from the presence of eating-related addictive behaviour. These do not fall within the scope of food addiction symptoms, however,
YFAS 2.0, które następnie poddano badaniu równoważności językowej metodą odpowiedzi dwujęzycznych na próbie 18 studentów ostatniego roku filologii angielskiej [39]. Połowie badanych dano do wypełnienia polską, a drugiej połowie angielską wersję narzędzia. Po dwóch tygodniach badanie powtórzono, aplikując odmienną wersję językową YFAS 2.0. Uzyskane wyniki poddano pod dyskusję zespołu i wprowadzono modyfikacje w tłumaczeniu kilku stwierdzeń, zachowując ich trafność treściową zgodnie z kryteriami uzależnień z DSM-5 [3] i kluczem odpowiedzi YFAS 2.0 [40, 41].

Do drugiego etapu badań przystąpiono, posługując się tak zweryfikowaną wersją kwestionariusza. Pozycje YFAS $2.0 \mathrm{w}$ oryginalnej i polskiej wersji językowej znajdują się w Aneksie. Na drugim etapie 76 studentów kursu psychologii zaburzeń odżywiania poddano grupowemu badaniu metodą test-retest, w odstępie trzech tygodni między badaniami. Celem tego badania było określenie bezwzględnej stałości czasowej wyników [35]. W reteście wzięło udział 50 studentów. Po zakończeniu własnego udziału w badaniu zaproszono wybranych studentów do współpracy w zbieraniu danych i odpowiednio ich w tym celu wyszkolono.

$\mathrm{Na}$ trzecim etapie badania prowadzono indywidualnie. Wszyscy uczestnicy byli na początku krótko informowani o celu badania, jego przebiegu i formie, dobrowolnym udziale, zachowaniu anonimowości i poufności przekazywanych informacji. Po wyrażeniu zgody na udział w badaniu zebrano od nich podstawowe dane demograficzne oraz dotyczące wagi i wzrostu. Następnie badani wypełniali wszystkie kwestionariusze walidacyjne $\mathrm{z}$ ich standardowymi instrukcjami: YFAS 2.0, SZJ, SCS i TFEQ-13.

\section{Narzędzia}

Yale Food Addiction Scale 2.0 (YFAS 2.0) Gearhardt, Corbin \& Brownell [16] (patrz Aneks) służy do oceny występowania zachowań nałogowych związanych z jedzeniem w ciągu ostatnich 12 miesięcy. Skala składa się z 35 pozycji, które osoba badana ocenia na 8-punktowej skali odpowiedzi, od 0 - „nigdy” do 7 - „codziennie”. Dwa stwierdzenia (16 i 17 - patrz Aneks) dotyczą klinicznie istotnego upośledzenia lub cierpienia wynikającego z obecności zachowań nałogowych związanych $z$ jedzeniem. Nie wchodzą one w zakres objawów uzależnienia od jedzenia, ale wymagane jest speł- 
this criterion is required for the diagnosis of food dependence.

The way in which the diagnostic score is calculated is quite complicated, so it is recommended using a spreadsheet for this purpose. For each question, a specific cut-off point was determined for making diagnosis and to assess the level of given symptom severity. The cutoffs for the YFAS 2.0 symptom questions were determined by examining the specificity of each response option using the Receiver Operator Characteristic (ROC) curve [16, 40]. For example, the lowest cut-off is the response "once a month" for statements: 9, 10, 27, 33 and 35, and the highest is "four to six times a week" for statements: 1, 2, 4, 6, 7, 15, 25 (for the content of the statements and the category to which they belong see Annex). If a threshold score is reached, the response receives the value 1 and if otherwise 0. After calculating the threshold for each statement, the scores are summed under each criterion (e.g., 6 for tolerance, 7 for withdrawal, 12 for clinical validity). If the score for a criterion symptom is $\geq 1$, then the criterion is met and 1 point is awarded. If the score $=0$, the criterion symptom is not met and 0 points are awarded. The number of symptoms (from 0 no symptom to 1 occurrence of symptom) revealed by the subject can be calculated by summing up all symptoms. The minimum diagnostic result is 0 and maximum 11 [16].

Moreover, based on the diagnostic criteria of addiction presented in DSM-5 [3], the results obtained can be differentiated in terms of the severity of food addiction as 1 - mild (presence of two or three symptoms), 2 - moderate (presence of four or five symptoms) and 3 - severe (presence of six or more symptoms). Food addiction is not diagnosed if only one or no symptom is present and the $12^{\text {th }}$ criterion of clinical validity is not fulfilled. Detailed instructions for calculating the results are available at https://fastlab. psych.lsa.umich.edu/yale-food-addiction-scale/ [40] and in Grzegorzewska and Cierpiałkowska manual [41: 312-313].

The Scale of Involvement on Eating Behaviour by Ogińska-Bulik [36] measures the degree of food absorption and the risk of food addiction. The scale contains 18 statements to which the subject can respond using a 5-step Likert type scale, where 0 means "almost never" nienie tego kryterium przy diagnozie uzależnienia od jedzenia.

Sposób obliczenia wyniku diagnostycznego jest dość skomplikowany, dlatego zaleca się wykorzystanie w tym celu arkusza kalkulacyjnego. Dla każdego pytania został określony specyficzny punkt odcięcia umożliwiający postawienie diagnozy i określenie poziomu nasilenia danego objawu. Progi punktowe dla pytań dotyczących symptomów YFAS 2.0 zostały określone przez zbadanie specyfiki każdej z opcji odpowiedzi na podstawie krzywej ROC (receiver operator characteristic) $[16,40]$. Dla przykładu, najniższy próg odcięcia stanowi odpowiedź „raz w miesiącu” dla stwierdzeń: 9., 10., 27., 33. i 35., a najwyższy odpowiedź „,cztery do sześciu razy w tygodniu” dla stwierdzeń: 1., 2., 4., 6., 7., 15., 25. (treść stwierdzeń i kategoria, do której przynależą, patrz: Aneks). Jeśli próg punktowy jest osiągnięty, wówczas odpowiedź uzyskuje wartość 1 , a w przeciwnym wypadku - 0 . Po obliczeniu progu dla każdego stwierdzenia sumuje się je pod każdym kryterium (np. 6 - tolerancja, 7 - odstawienie, 12 - trafność kliniczna). Jeśli wynik dla symptomu kryterialnego wynosi $\geq 1$, wtedy kryterium jest spełnione i przyznaje mu się 1 punkt. Jeśli wynik wynosi 0 , wtedy symptom kryterialny nie jest spełniony i przyznaje mu się 0 punktów. Ostatecznie liczbę objawów (od 0 - brak objawu, do 1 - wystąpienie objawu) ujawnianych przez osobę badaną można obliczyć, sumując je. Minimalny wynik diagnostyczny wynosi 0 , a maksymalny 11 [16].

Ponadto na podstawie kryteriów diagnostycznych uzależnień przedstawionych w DSM-5 [3] uzyskane wyniki można różnicować pod kątem nasilenia uzależnienia od jedzenia na: 1 - łagodne (obecność dwóch lub trzech objawów), 2 - umiarkowane (obecność czterech lub pięciu objawów), 3 - ciężkie (obecność sześciu lub więcej objawów). Nie stwierdza się uzależnienia od jedzenia, jeśli potwierdzony jest tylko jeden objaw lub żaden oraz niespełnione jest 12 . kryterium trafności klinicznej. Szczegółowa instrukcja obliczania wyników i ich interpretacji znajduje się na stronie https:// fastlab.psych.lsa.umich.edu/yale-food-addiction -scale/ [40] oraz w podręczniku Grzegorzewskiej i Cierpiałkowskiej [41: 312-313].

Skala Zaabsorbowania Jedzeniem (SZJ) Ogińskiej-Bulik [36] mierzy stopień zaabsorbowania jedzeniem i ryzyka uzależnienia od jedzenia. Zawiera 18 stwierdzeń, na które osoba badana może odpowiedzieć, korzystając z 5-stopniowej skali typu Likerta, gdzie 0 oznacza „prawie nigdy”, a 5 
and 5 means "almost always". The questionnaire allows the measurement of the overall score and the components 1) preoccupation and concentration on eating activities; 2) eating to enhance pleasure and improve mood; 3 ) craving and loss of control over eating. The higher the overall score, the more food absorption and risk of addiction to food. The internal consistency of questionnaire measured by Cronbach's $\alpha=0.89$ and the absolute time stability measured by the correlation coefficient in the test-retest studies (after six weeks) was 0.72 [36].

Three-Factor Eating Questionnaire-13 (TFEQ13) is an abbreviated version of TFEQ Karlsson et al. [37] in the Polish adaptation of Dzielska et al. [42], which is used to assess problematic eating behaviour. The scale contains 13 statements, to which the studied person responds using a 4 -stage Likert type scale, where 0 means "definitely no" and 3 means "definitely yes". The questionnaire measures three aspects of food-related problems 1) uncontrolled eating (TFEQ-C), 2) cognitive restraint of eating (TFEQ-R) and 3) emotional eating (TFEQ-E). The higher the sum of the points, the greater the severity of each individual eating-related problem. Cronbach's a internal consistency factor $\alpha=0.78$ [42].

Self-Control Scale (SCS) by Tangney, Baumeister and Boone [38] in Poprawa's Polish adaptation [43] is used to measure self-control, i.e., the ability to control or change internal reactions as well as to interrupt and refrain from revealing unwanted behavioural tendencies (such as impulses). It consists of 36 statements, rated on a Likert type scale from 1 "strongly disagree" to 5 "strongly agree". The higher the sum of the responses (after reversing the negative responses), the greater the ability to self-control. The tool showed very good reliability as item-total correlation ranged from 0.301 to 0.686 , Cronbach's $\alpha=0.898$, splithalf reliability $=0.914[43]$.

\section{Data analyses}

Data were recorded in an Excel spreadsheet, which facilitated the complex procedure of converting raw data into diagnostic results. The analyses were carried out using the StatSoft, Inc. package STATISTICA v.12 and SPSS Amos v.25. Initially, descriptive statistics were performed and the compliance of YFAS 2.0 results with
- „prawie zawsze”. Kwestionariusz umożliwia pomiar wyniku ogólnego oraz trzech składowych: 1) zaabsorbowanie i koncentracja na czynności jedzenia; 2) jedzenie w celu dostarczenia sobie przyjemności i poprawy nastroju; 3) przymus, pożądanie jedzenia i utrata kontroli nad nim. Im wyższy wynik ogólny, tym większe zaabsorbowanie jedzeniem i ryzyko uzależnienia od jedzenia. Zgodność wewnętrzna kwestionariusza a Cronbacha wyniosła 0,89, a bezwzględna stałość czasowa mierzona za pomocą współczynnika korelacji w badaniach test-retest (po upływie sześciu tygodni) - 0,72 [36].

Three-Factor Eating Questionnaire-13 (TFEQ-13) to skrócona wersja TFEQ Karlsson i wsp. [37] w polskiej adaptacji Dzielskiej i wsp. [42]. Narzędzie to służy do oceny problemowych zachowań związanych $\mathrm{z}$ jedzeniem. Zawiera 13 stwierdzeń, na które osoba badana może odpowiedzieć, korzystając z 4-stopniowej skali typu Likerta, gdzie 0 oznacza „zdecydowanie nie”, a 3 - „zdecydowanie tak”. Kwestionariusz umożliwia pomiar trzech aspektów problemów związanych z jedzeniem: 1) braku kontroli nad jedzeniem (TFEQ-C), 2) ograniczania jedzenia (TFEQ-R) oraz 3) jedzenia na podłożu emocjonalnym (TFEQ-E). Im wyższa suma punktów, tym większe nasilenie każdego problemu związanego z jedzeniem z osobna. Współczynnik zgodności wewnętrznej a Cronbacha wyniósł 0,78 [42].

Self-Control Scale (SCS) Tangney, Baumeister i Boone [38] w polskiej adaptacji Poprawy [43] służy do pomiaru samokontroli, czyli zdolności do sterowania czy zmieniania wewnętrznych reakcji, jak również przerywania niepożądanych behawioralnych tendencji (takich jak impulsy) i powstrzymywania się od ich ujawnienia. Składa się z 36 stwierdzeń ocenianych na skali typu Likerta od $1-$ „zdecydowanie nie zgadzam się” do 5 - „zdecydowanie zgadzam się". Im wyższa suma odpowiedzi (po odwróceniu odpowiedzi sformułowanych negatywnie), tym większa zdolność do samokontroli. Narzędzie cechuje się bardzo dobrą rzetelnością: moc dyskryminacyjna pozycji wahała się od 0,301 do 0,686 , a Cronbacha wyniosło 0,898 , a współczynnik rzetelności połówkowej - 0,914 [43].

\section{Analiza danych}

Dane zapisywano w arkuszu kalkulacyjnym Excel, co ułatwiało przeprowadzanie skomplikowanej procedury przeliczania danych surowych na wyniki diagnostyczne. Do analiz wykorzystano pakiet StatSoft, Inc. STATISTICA v.12 oraz SPSS Amos v. 25. 
normal distribution was tested with the Kolgomorov-Smirnov test. The Wald-Wolfowitz series test examined the differences between the sexes in YFAS 2.0 diagnostic results. The percentage distributions of the severity of symptoms of food addiction throughout the entire test sample were analysed. The percentage distribution of the subjects meeting the criteria of food addiction depending on BMI results exceeding the standard was also compared.

To confirm the validity of YFAS 2.0, in the first step a procedure consistent with the original study was used [16]. Confirmatory factor analysis (CFA) was performed on YFAS 2.0 dichotomous diagnostic data, which for each criterion of specific studied person is valued from 0 to 1 (see above description of the tool). Overall diagnostic result, i.e., the severity of symptoms of food addiction was in tested model a latent variable. CFA was carried out using ADF method that is asymptotically distribution-free estimates. This type of estimation does not require the assumption of multidimensional normality, which is appropriate for diagnostic results of YFAS 2.0 that do not have a normal distribution (see Results - descriptive statistics). Several goodness-of-fit indicators and empirical data discrepancies with the YFAS 2.0 theoretical model were adopted. Rather than using the statistics loaded $\chi^{2}$, the indicator $\chi^{2} / d f$ was adopted, which removes the limitation of $\chi^{2}$ statistics and should not exceed a value of 3.0. The SRMS (standardized root mean square) indicator is an index of bad fit, the higher the values the worse the fit, it takes values from 0.0 to 1.0 . Approximately this indicator should be $\leq 0.08$ for a good fit in practical terms. The CFI (comparative fit index), on the other hand, takes values from 0 to 1 and the closer to 1 the better the fit. A CFI value $\geq 0.95$ indicates a very good match between the model and the data. RMSEA (root mean square error of approximation), with values above 0.10 indicates an insufficient fit, while values below 0.05 indicate a very good fit. The GFI (goodness-of-fit index) and AGFI (adjusted goodness-of-fit index) to indicate a good fit should be $\geq 0.95[44,45]$.

The reliability of YFAS 2.0 was assessed on the basis of a) absolute time stability measured by Pearson's $r$ between test and retest results with respect to subscale and overall result; b) Cronbach's $a$ internal consistency, both between subscales and
Na początek wykonano statystyki opisowe i zbadano testem Kołgomorowa-Smirnowa zgodność wyników z rozkładem normalnym. Zbadano testem serii Walda-Wolfowitza różnice między płciami w wynikach diagnostycznych YFAS 2.0. Przeanalizowano rozkłady procentowe nasilenia symptomów uzależnienia od jedzenia w całej badanej próbie. Porównano też rozkład procentowy badanych spełniających kryteria uzależnienia w zależności od przekraczających normę wyników BMI.

$\mathrm{W}$ celu potwierdzenia trafności YFAS 2.0 na początek zastosowano procedurę zgodną z badaniami oryginalnymi [16]. Przeprowadzono konfirmacyjną analizę czynnikową (CFA) na dychotomicznych danych diagnostycznych YFAS 2.0, które dla każdego kryterium u konkretnej osoby badanej przyjmują wartość 0 lub 1 (patrz: powyżej opis narzędzia). Ogólny wynik diagnostyczny, czyli nasilenie symptomów uzależnienia od jedzenia, w testowanym modelu był zmienną ukrytą. CFA przeprowadzono metodą ADF, czyli estymacji asymptotycznie niezależnej od rozkładu. Ten rodzaj estymacji nie wymaga założenia normalności wielowymiarowej, co jest założeniem właściwym w przypadku wyników diagnostycznych YFAS 2.0, które nie mają rozkładu normalnego (patrz: Wyniki - statystyki opisowe). Przyjęto kilka wskaźników dobroci dopasowania i rozbieżności danych empirycznych $\mathrm{z}$ modelem teoretycznym YFAS 2.0. Zamiast posługiwać się obciążoną statystyką $\chi^{2}$ przyjęto wskaźnik $\chi^{2} / d f$, który niweluje ograniczenie statystyki $\chi^{2}$ i nie powinien przekraczać wartości 3,0. Wskaźnik SRMS jest indeksem złego dopasowania (im większe wartości, tym gorsze dopasowanie) i przyjmuje wartości od 0,0 do 1,0 . $\mathrm{W}$ przybliżeniu ten wskaźnik powinien być $\leq 0,08$, aby dopasowanie było $\mathrm{w}$ sensie praktycznym dobre. Z kolei CFI przyjmuje wartości od 0 do 1 im są bliższe 1, tym lepsze dopasowanie. Wartość CFI $\geq 0,95$ wskazuje na bardzo dobre dopasowanie modelu do danych. RMSEA, którego wartości powyżej 0,10 świadczą o niedostatecznym dopasowaniu, natomiast poniżej 0,05 - o bardzo dobrym. Wskaźniki GFI i AGFI, jeśli mają wartość $\geq 0,95$, to wskazują na dobre dopasowanie $[44,45]$.

Rzetelność YFAS 2.0 oceniano na podstawie kilku wskaźników: a) bezwzględnej stałości czasowej mierzonej $r$ Pearsona między wynikami testu i retestu, w odniesieniu do wyników w podskalach i wyniku ogólnego; b) zgodności wewnętrznej a Cronbacha, zarówno poszczególnych podskal, jak 
overall result and c) item-total correlation within each subscale $\left(r_{i t}\right)$. All analyses were performed on raw data.

In order to further assess the validity of the Polish version of YFAS 2.0, analyses of recalculated subscale results correlation (without taking into account the $12^{\text {th }}$ clinical criterion) and overall YFAS 2.0 result with the accepted validity indicators were performed. A non-parametric variant of Spearman's $r$ correlation analysis was used due to the distribution of YFAS 2.0 results being abnormal. A series of single-factor ANOVA was also carried out in the range of accepted validity indicators depending on the severity of symptoms of food addiction determined with YFAS 2.0. The significance of differences in YFAS 2.0 diagnostic results between compared groups: normative, FAA and participants in the weightloss programme was also investigated using the Kruskal-Wallis test.

\section{- Results}

\section{Descriptive statistics and gender differences}

Figure 1 shows the percentage distribution of confirmed symptoms of food addiction, without criterion 12 ("occurrence of distress and life problems caused by eating"). The mean of confirmed symptoms in the examined sample was $\mathrm{M}=2.40$ with $\mathrm{SD}=3.24$. The distribution of obtained results did not fit normal distribution (Kolgomorov-Smirnov's test $d=0.25, p<0.01$ ) being clearly right-skewed distribution, i.e., there were significantly more low than high results. Over $42 \%$ persons did not meet any of the 11 addiction diagnostic criteria while $5.1 \%$ met all criteria (Figure 1). The Wald-Wolfowitz series test showed no significant differences (all $p>0.1$ ) between women and men both because of the overall YFAS 2.0 and each of the 11 diagnostic criteria.

With respect to study sample results in the light of the assumed diagnostic criteria, in the group that confirmed the symptoms, $10.9 \%$ (47 persons) can be described as severely addicted to food, $2.32 \%$ (10 persons) as moderate and $1.16 \%$ (5 persons) as light. The percentage distribution of subjects in the study sample with a body-mass index (BMI) above the norm, i.e., overweight, obese and clinically obese according to the degree of food addiction (FA), was also analysed. In the group meet- i wyniku ogólnego; c) mocy dyskryminacyjnej pozycji w obrębie każdej podskali $\left(r_{i t}\right)$. Wszystkie te analizy przeprowadzono na danych surowych.

W celu dalszej oceny trafności polskiej wersji YFAS 2.0 przeprowadzono analizy korelacji wyników przeliczonych podskal (bez uwzględniania 12. kryterium klinicznego) i wyniku ogólnego YFAS $2.0 \mathrm{z}$ przyjętymi wskaźnikami trafności. Zastosowano nieparametryczną odmianę analizy korelacji $r$ Spearmana ze względu na niezgodny z normalnym rozkład wyników YFAS 2.0. Przeprowadzono również serię jednoczynnikowych ANOVA w zakresie przyjętych wskaźników trafności w zależności od stopnia nasilenia symptomów uzależnienia od jedzenia określonych za pomocą YFAS 2.0. Posługując się testem Kruskala-Wallisa, zbadano również istotność różnic w wynikach diagnostycznych YFAS 2.0 między porównywanymi grupami: normatywną, FAA i osób uczestniczących w programie odchudzająco-kondycyjnym.

\section{- WYNIKI}

\section{Statystyki opisowe i różnice między płciami}

Na rycinie 1 przedstawiono rozkład procentowy potwierdzonych objawów uzależnienia od jedzenia, bez uwzględnienia kryterium 12. („wystąpienie dystresu i problemów życiowych spowodowanych sposobem odżywania się"). Średnia potwierdzonych objawów w badanej próbie to $\mathrm{M}=2,40 \mathrm{z} \mathrm{SD}=3,24$. Rozkład wyników nie pasował do normalnego (test Kołgomorowa-Smirnowa: $d=0,25, p<0,01$ ), był ewidentnie prawostronnie skośny, tzn. badani uzyskali znacząco więcej wyników niskich niż wysokich. Ponad $42 \%$ osób nie spełniło żadnego z 11 kryteriów diagnostycznych uzależnienia, a 5,1\% spełniło wszystkie kryteria (ryc. 1). Test serii Walda-Wolfowitza nie wykazał istotnych różnic (wszystkie $p>0,1$ ) między kobietami i mężczyznami - zarówno w wyniku ogólnym YFAS 2.0, jak i w każdym z 11 kryteriów diagnostycznych.

Odnosząc wyniki badanej próby do założonych kryteriów diagnostycznych, w grupie, która potwierdzała objawy, 10,9\% (47 osób) można określić jako uzależnione od jedzenia w stopniu ciężkim, 2,32\% (10 osób) - umiarkowanym, a 1,16\% (5 osób) - lekkim. Przeanalizowano też procentowy rozkład osób z badanej próby z BMI powyżej normy, tj. z nadwagą, otyłych i klinicznie otyłych, pod kątem stopnia uzależnienia od jedzenia (FA). W grupie spełniającej najwyższy stopień uzależ- 


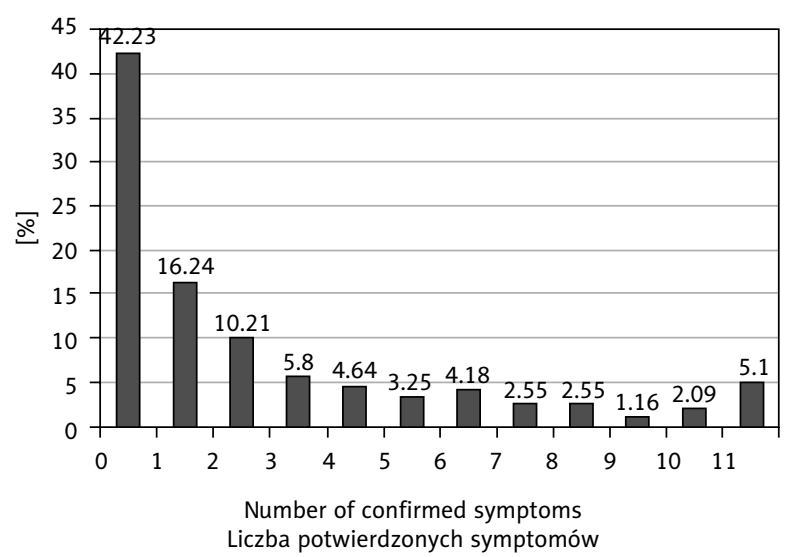

Figure 1. Percent distribution of confirmed symptoms of food addiction in the sample Rycina 1. Rozkład procentowy potwierdzonych symptomów uzależnienia od jedzenia w badanej próbie

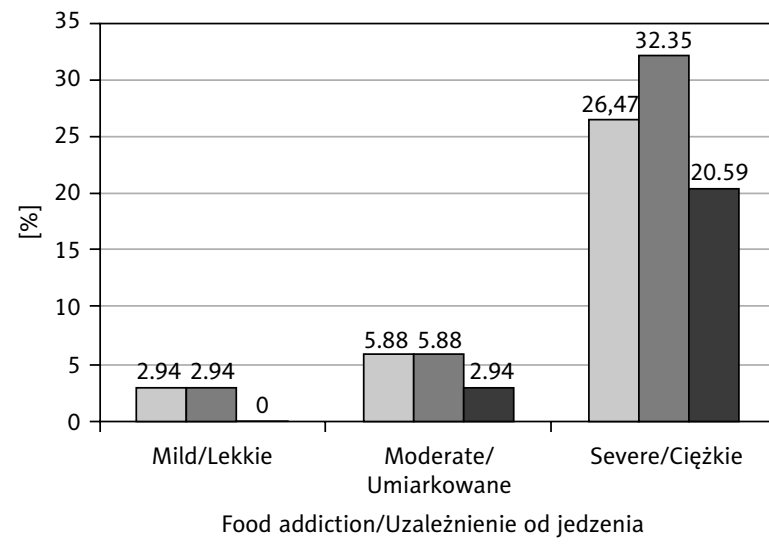

$\square$ Overweight/Nadwaga $\square$ Obese/Otyłość

$\square$ Clinical obese/Kliniczna otyłość

Figure 2. Food addiction prevalence by weight class

Rycina 2. Procent uzależnionych od jedzenia w zależności od ponadnormatywnego BMI

ing the highest level of food dependence, most were persons both overweight $(26.47 \%)$, obese $(32.35 \%)$ and clinically obese $(20.59 \%)$. There were significantly fewer in the group with the diagnosis of moderate intensity of symptoms at $5.88 \%$, $5.88 \%$ and $2.94 \%$ respectively. The lowest number of people exceeding the normative BMI indicator was among those diagnosed as having a mild degree of food dependence at $2.94 \%$ - overweight, $2.94 \%$ - obese and $0 \%$ - clinically obese (Figure 2).

\section{Construct validity and reliability of Polish version YFAS 2.0}

As a result of confirmatory factor analysis (CFA) for dichotomous diagnostic data, the following values of accepted indicators were obtained: $c^{2} / d f$ 1.81; SRMS 0.01; RMSEA 0.04; CFI 0.90, GFI 0.99 and AGFI 0.99. All factor loads $(\beta)$ of subscales (included in the last right column of Annex) were significant $(p<0.001)$ and high from 0.57 to 0.86 . nienia od jedzenia najwięcej było osób zarówno z nadwagą (26,47\%), jak i otyłych $(32,35 \%)$ oraz klinicznie otyłych $(20,59 \%)$. W grupie z uzależnieniem $\mathrm{w}$ stopniu umiarkowanym stwierdzono ich znacząco mniej, odpowiednio: 5,88\%, 5,88\% i 2,94\%. Najmniej osób przekraczających normatywny wskaźnik BMI było wśród osób spełniających kryteria uzależnienia od jedzenia w stopniu lekkim, odpowiednio: 2,94\%, 2,94\% i 0\% (ryc. 2).

\section{Trafność teoretyczna i rzetelność polskiej wersji YFAS 2.0}

W wyniku konfirmacyjnej analizy czynnikowej (CFA) dla dychotomicznych danych diagnostycznych uzyskano następujące wartości przyjętych wskaźników: $c^{2} / d f$ 1,81; SRMS 0,01; RMSEA 0,04; CFI 0,90, GFI 0,99 i AGFI 0,99. Wszystkie ładunki czynnikowe $(\beta)$ podskal (zawiera je ostatnia prawa kolumna Aneksu) były istotne $(p<0,001)$ i wysokie - od 0,57 do 0,86. 
The item-total correlation values were generally high $\left(r_{i t}>0.5\right)$, except for item 28 , whose $r_{i t}=0.34$ was relatively low but acceptable [35]. The internal consistency measured by Cronbach's $a$ of the whole questionnaire as well as individual subscales was very high, except for subscale 10 , for which it was only 0.64 , but acceptable [35]. The removal of item 28 , with a low correlation coefficient with the overall result, significantly increased the Cronbach's $\alpha$ of subscale 10 to 0.86 .

All test-retest correlation coefficients (absolute time stability assessment), both the overall YFAS 2.0 score and its subscales, were significant and had very high values $\left(r_{t r}>0.7\right)$. Except for subscale 11. with high $r_{t r}=0.64$. The reliability indicators of the measurement of the additional $12^{\text {th }}$ subscale, which is the criterion of so-called clinical validity, was also significant and high or very high. All detailed results of the discussed analyses are presented in Annex.

\section{Various aspects of Polish translation YFAS 2.0 validity}

The analysis of correlation between the accepted validity indicators and YFAS 2.0 results was carried out, as in the original study [16], on diagnostic data not taking into account criterion 12 . Body weight and BMI significantly though poorly correlated positive with the overall YFAS 2.0 score and its subscales (Table I).

The YFAS 2.0 score correlated significantly very high positively with the overall score of the Scale of Involvement on Eating Behaviour (SZJ) (0.70) and high with its subscales, i.e., 1 - "preoccupation and concentration on eating activities" (0.60), 2 - "enhancing pleasure and improving mood" (0.51), 3 - "craving and loss of control over eating" (0.65). Moreover, each symptom of food addiction measured by YFAS 2.0 correlated significantly positively with the overall SZJ score and its subscales results. These correlation values ranged from 0.30 to 0.56 (see Table I).

It was also found that the overall YFAS 2.0 score correlated significantly high positively with uncontrolled eating (TFEQ-C) and emotional eating (TFEQ-E). Also, the individual subscales YFAS 2.0 correlated significantly ( 0.38 to 0.46$)$, both with uncontrolled and emotional eating. The cognitive restraint of eating (TFEQ-R), on the other hand, did not correlate significantly with the overall result and most of the YFAS 2.0
Wartości mocy dyskryminacyjnych pozycji były ogólnie wysokie $\left(r_{i t}>0,5\right)$, z wyjątkiem pozycji 28., której wartość była względnie niska, ale akceptowalna $\left(r_{i t}=0,34\right)$ [35]. Mierzona a Cronbacha zgodność wewnętrzna zarówno całego kwestionariusza, jak i poszczególnych podskal była bardzo wysoka, z wyjątkiem podskali 10., dla której wyniosła 0,64 , co jest akceptowalne [35]. Usunięcie pozycji 28. o niskim współczynniku korelacji z wynikiem ogólnym znacząco podwyższało a Cronbacha podskali 10. do wartości 0,86 .

Wszystkie współczynniki korelacji test-retest (oceny bezwzględnej stałości czasowej), dotyczące zarówno ogólnego wyniku YFAS 2.0, jak i jego podskal, osiągnęły istotność statystyczną i bardzo wysokie wartości $\left(r_{t r}>0,7\right)$. Z wyjątkiem podskali 11. o wysokim $r_{t r}=0,64$. Wskaźniki rzetelności pomiaru dodatkowej, 12. podskali, stanowiącej kryterium tzw. trafności klinicznej, były również istotne i wysokie lub bardzo wysokie. Szczegółowe rezultaty omawianych analiz zawiera Aneks.

\section{Różne aspekty trafności polskiego tłumaczenia YFAS 2.0}

Analizę korelacji przyjętych wskaźników trafności z wynikami YFAS 2.0 przeprowadzono - tak jak w badaniach oryginalnych [16] - na danych diagnostycznych nieuwzględniających kryterium 12. Masa ciała oraz BMI istotnie, ale słabo pozytywnie korelowały z ogólnym wynikiem YFAS 2.0 i jego podskalami (tab. I).

Wynik YFAS 2.0 korelował istotnie pozytywnie bardzo wysoko z wynikiem ogólnym Skali Zaabsorbowania Jedzeniem (SZJ) $(0,70)$ oraz wysoko z jego podskalami, tj. 1 - „zaabsorbowanie i koncentracja na czynności jedzenia” $(0,60), 2$ - ,jedzenie w celu dostarczenia sobie przyjemności i poprawy nastroju” (0,51), 3 - „przymus, pożądanie jedzenia i utrata kontroli nad nim" $(0,65)$. Ponadto każdy objaw uzależnienia od jedzenia mierzony YFAS 2.0 istotnie korelował pozytywnie z wynikiem ogólnym SZJ i wynikami jej podskal. Wartości tych korelacji wahały się od 0,30 do 0,56 (patrz: tab. I).

Stwierdzono również, że wynik ogólny YFAS 2.0 korelował istotnie wysoko pozytywnie z trudnościami kontroli jedzenia (TFEQ-C) oraz jedzeniem na podłożu emocjonalnym (TFEQ-E). Również poszczególne podskale YFAS 2.0 korelowały istotnie (od 0,38 do 0,46) z trudnościami kontroli jedzenia oraz jedzeniem emocjonalnym. Natomiast stosowanie restrykcji jedzeniowych (TFEQ-R) nie korelo- 
Table I. Association of YFAS 2.0 symptoms with convergent validity measures: body weight, BMI, Three Factor Eating Questionnaire (TFEQ-13) and Scale of Involvement on Eating Behaviour (SZJ)

Tabela I. Związki objawów YFAS 2.0 z miarami trafności zbieżnej: masą ciała, BMI, Trzyczynnikowym Kwestionariuszem Jedzenia (TFEQ-13) i Skalą Zaabsorbowania Jedzeniem (SZJ)

\begin{tabular}{|c|c|c|c|c|c|c|c|c|c|c|}
\hline \multirow{2}{*}{$\begin{array}{l}\text { YFAS } 2.0 \\
\text { Subscales/Podskale }\end{array}$} & \multirow[b]{2}{*}{$\begin{array}{l}\text { Body weight } \\
\text { Masa ciała }\end{array}$} & \multirow[b]{2}{*}{ BMI } & \multicolumn{4}{|c|}{ SZJ } & \multicolumn{3}{|c|}{ TFEQ } & \multirow[t]{2}{*}{ SCS } \\
\hline & & & 1 & 2 & 3 & $\begin{array}{l}\text { Total } \\
\text { Ogótem }\end{array}$ & C & $R$ & $\mathrm{E}$ & \\
\hline $\begin{array}{l}\text { 1. Consumed more than planned } \\
\text { Jedzenie więcej niż planowano }\end{array}$ & $0.15^{* *}$ & 0.17 & 0.44 & 0.38 & 0.53 & 0.53 & 0.43 & $-0.16^{* *}$ & 0.39 & -0.40 \\
\hline $\begin{array}{l}\text { 2. Unable to cut down or stop } \\
\text { Niemożność przerwania jedzenia }\end{array}$ & $0.15^{* *}$ & 0.19 & 0.48 & 0.37 & 0.48 & 0.51 & 0.44 & $-0.04^{\mathrm{ns}}$ & 0.43 & -0.33 \\
\hline $\begin{array}{l}\text { 3. Great deal of time spent } \\
\text { Spędzanie dużej ilości czasu na } \\
\text { jedzeniu }\end{array}$ & 0.22 & 0.23 & 0.44 & 0.38 & 0.47 & 0.51 & 0.43 & $-0.15^{* *}$ & 0.34 & -0.39 \\
\hline $\begin{array}{l}\text { 4. Important activities given up } \\
\text { Zaniedbanie ważnych aktywności }\end{array}$ & 0.19 & 0.19 & 0.52 & 0.38 & 0.38 & 0.49 & 0.43 & $0.08^{\text {ns }}$ & 0.43 & -0.31 \\
\hline $\begin{array}{l}\text { 5. Use despite physical/emotional } \\
\text { consequences } \\
\text { Jedzenie pomimo negatywnych } \\
\text { konsekwencji }\end{array}$ & 0.20 & 0.22 & 0.49 & 0.38 & 0.42 & 0.50 & 0.38 & $-0.04^{\mathrm{ns}}$ & 0.38 & -0.37 \\
\hline $\begin{array}{l}\text { 6. Tolerance } \\
\text { Tolerancja }\end{array}$ & 0.17 & 0.20 & 0.46 & 0.30 & 0.39 & 0.44 & 0.41 & $-0.02^{\mathrm{ns}}$ & 0.40 & -0.32 \\
\hline $\begin{array}{l}\text { 7. Withdrawal } \\
\text { Objawy odstawienne }\end{array}$ & $0.15^{* *}$ & 0.18 & 0.52 & 0.38 & 0.46 & 0.52 & 0.43 & $-0.03^{n s}$ & 0.46 & -0.38 \\
\hline $\begin{array}{l}\text { 8. Use despite interpersonal/social } \\
\text { consequences } \\
\text { Jedzenie mimo problemów } \\
\text { w relacjach z otoczeniem }\end{array}$ & 0.28 & 0.29 & 0.53 & 0.42 & 0.49 & 0.56 & 0.46 & $0.03^{\text {ns }}$ & 0.41 & -0.38 \\
\hline $\begin{array}{l}\text { 9. Failure in role obligation } \\
\text { Niepowodzenia w wykonywaniu } \\
\text { obowiązków }\end{array}$ & 0.21 & 0.21 & 0.49 & 0.36 & 0.39 & 0.48 & 0.40 & $0.06^{\mathrm{ns}}$ & 0.42 & -0.35 \\
\hline $\begin{array}{l}\text { 10. Use in physically hazardous } \\
\text { situations } \\
\text { Stosowanie w fizycznie } \\
\text { niebezpiecznych sytuacjach }\end{array}$ & 0.20 & 0.19 & 0.50 & 0.48 & 0.56 & 0.60 & 0.46 & $-0.08^{\mathrm{ns}}$ & 0.42 & -0.48 \\
\hline $\begin{array}{l}\text { 11. Craving } \\
\text { Głód/pożądanie }\end{array}$ & $0.15^{* *}$ & 0.16 & 0.50 & 0.42 & 0.48 & 0.54 & 0.43 & $-0.06^{\mathrm{ns}}$ & 0.45 & -0.39 \\
\hline $\begin{array}{l}\text { Overall result } \\
\text { Wynik ogólny }\end{array}$ & 0.20 & 0.20 & 0.60 & 0.51 & 0.65 & 0.70 & 0.56 & $-0.05^{\mathrm{ns}}$ & 0.54 & -0.50 \\
\hline
\end{tabular}

$B M I$ - body mass index/wskaźnik masy ciata

TFEQ - Three-Factor Eating Questionnaire, C (uncontrolled eating/brak kontroli nad jedzeniem), $R$ (cognitive restraint of eating/restrykcje jedzeniowe), E (emotional eating/emocjonalne jedzenie)

SZJ Scale of Involvement on Eating Behaviour - 1 (preoccupation and concentration on eating activities/zaabsorbowanie $i$ koncentracja na czynności jedzenia), 2 (enhancing pleasure and improving mood/wzmaganie przyjemności i poprawa nastroju), 3 (craving and loss of control over eating/poczucie przymusu i utrata kontroli nad jedzeniem)

SCS Self-Control Scale/Skala Samokontroli

Unlabelled coefficients statistically significant with $p<0.001$, others: ${ }^{* *} p<0.01$; ns - not significant/Nieoznaczone wspótczynniki istotne statystycznie $z p<0,001$, pozostate: * $p<0,01$; ns - nieistotne

Note/Uwaga: The analyses were performed on diagnostic data calculated without taking into account the clinical criterion./Analizy przeprowadzono na danych diagnostycznych obliczonych bez użycia kryterium klinicznego.

subscales. Only a significant weak negative correlation was observed between cognitive restraint of eating and YFAS 2.0 subscale 1 - consumed more than planned and 3 - great deal of time spent on eating. wało istotnie $\mathrm{z}$ wynikiem ogólnym oraz większością podskal YFAS 2.0. Zaobserwowano jedynie istotną słabą negatywną korelację podskali 1. - jedzenie więcej niż planowano, i 3. - spędzanie dużej ilości czasu na jedzeniu ze stosowaniem restrykcji jedzeniowych. 
Table II. Differences in the validity measures depending on severity of symptoms of the food addiction (FA) Tabela II. Różnice w miarach trafności zależne od nasilenia symptomów uzależnienia od jedzenia

\begin{tabular}{|c|c|c|c|c|c|c|c|}
\hline & \multicolumn{4}{|c|}{$M(S D)$} & \multirow{3}{*}{$\mathrm{F}_{(3,424)}$} & \multirow{3}{*}{$\begin{array}{c}\text { Significant } \\
\text { pairwise } \\
\text { comparisons/p }\end{array}$} & \multirow{3}{*}{$\eta^{2}$} \\
\hline & \multirow{2}{*}{\begin{tabular}{|c|c}
$\begin{array}{c}0-\text { No FA } \\
\text { Brak }\end{array}$ \\
$n=361(85.61 \%)$ \\
\end{tabular}} & \multirow{2}{*}{$\begin{array}{c}\begin{array}{c}1-\text { Mild FA } \\
\text { Lekkie }\end{array} \\
n=5(1.16 \%)\end{array}$} & \multirow{2}{*}{$\begin{array}{l}2 \text { - Moderate FA } \\
\text { Umiarkowane } \\
n=9(2.32 \%)\end{array}$} & \multirow{2}{*}{$\begin{array}{c}3 \text { - Severe FA } \\
\text { Ciężkie }\end{array}$} & & & \\
\hline & & & & & & & \\
\hline $\begin{array}{l}\text { Weight } \\
\text { Masa }\end{array}$ & $70.87(17.41)$ & $76.40(19.50)$ & $78.11(28.22)$ & $80.66(21.47)$ & $4.43^{* *}$ & $0<2^{* * *}$ & 0.03 \\
\hline TFEQ-C & $5.02(2.84)$ & $6.60(3.85)$ & $8.00(3.80)$ & $9.55(3.14)$ & $36.07^{\star *}$ & $\begin{aligned} 0 & <2^{* *}, 3^{* * *} \\
& 1<3^{*}\end{aligned}$ & 0.20 \\
\hline TFEQ-E & $2.68(2.18)$ & $4.40(3.21)$ & $5.40(2.95)$ & $6.70(2.45)$ & $48.33^{* *}$ & $\begin{array}{c}0<1^{t}, 2 \& 3^{* * *} \\
1<2^{*}, 2<3^{t}\end{array}$ & 0.25 \\
\hline $\begin{array}{l}\text { SZJ total } \\
\text { ogólny }\end{array}$ & $44.60(11.55)$ & $46.20(17.21)$ & $57.80(10.88)$ & $69.53(10.46)$ & $68.03^{* *}$ & $\begin{array}{c}0<2 \& 3^{* * *} \\
1<2^{\mathrm{t}}, 3^{* * *} \\
2<3^{* *}\end{array}$ & 0.32 \\
\hline SZJ-1 & $12.34(4.65)$ & $15.40(4.72)$ & $20.60(3.75)$ & $23.77(4.49)$ & $92.44^{* *}$ & $\begin{array}{c}0<2 \& 3^{* * *} \\
1<2^{*}, 3^{* * *} \\
2<3^{*}\end{array}$ & 0.39 \\
\hline SZJ-2 & $17.00(4.86)$ & $14.60(6.11)$ & $19.00(3.77)$ & $23.00(4.57)$ & $22.27^{\star *}$ & $\begin{aligned} 0 & <3^{* \star *} \\
1 & <2^{t}, 3^{* * *} \\
2 & <3^{*}\end{aligned}$ & 0.14 \\
\hline SZJ-3 & $15.25(4.62)$ & $13.20(7.89)$ & $18.20(6.37)$ & 22.79 (3.99) & $37.22^{\star *}$ & $\begin{array}{c}0<2^{*}, 3^{* \star *} \\
1<3^{* *} \\
2<3^{* *}\end{array}$ & 0.21 \\
\hline SCS & $96.49(16.17)$ & $75.60(23.23)$ & $87.40(16.99)$ & $80.28(13.89)$ & $17.13^{* * *}$ & $0>1^{* *}, 2^{\mathrm{t}}, 3^{* * *}$ & 0.11 \\
\hline
\end{tabular}

Variable names as in Table I/Nazwy zmiennych jak $w$ Tabeli I

$M(S D)$ - mean (standard deviation)/średnia (odchylenie standardowe)

$\eta^{2}$ - eta ${ }^{2}$ - effect size/wielkość efektu; ${ }^{t} p<0.1,{ }^{*} p<0.05,{ }^{* *} p<0.01,{ }^{* * *} p<0.001$

Pairwise comparisons/porównanie parami

Numbers in brackets/liczby w nawiasach - \%

It was shown that the overall YFAS 2.0 score correlated significantly high negatively with selfcontrol ability $(-0.50)$. Also, all YFAS 2.0 subscales correlated significantly negatively with self-control ability ( -0.31 to -0.48$)$ (see Table I).

In accordance with the diagnostic criteria of YFAS 2.0, four groups of subjects with different degrees of severity of symptoms of food addiction (independent variable) were identified: 0 - no symptoms ( $85.61 \%$ of the sample), 1 - mild (1.16\%), 2 - moderate $(2.32 \%)$ and 3 - severe (10.9\%). ANOVA examined the significance of differences between these groups for the dependent variables: body weight, uncontrolled eating (TFEQ-C), emotional eating (TFEQ-E), overall score of food absorption (SZJ) and its sub-indices and self-control ability. The results of these analyses are presented in Table II.

It was found that body weight was to a small extent significantly dependent on the severity of symptoms. Only persons with moderate symptom severity (group 2) differed significantly from
Wykazano, że wynik ogólny YFAS 2.0 korelował istotnie wysoko negatywnie ze zdolnością do samokontroli $(-0.50)$. Wszystkie podskale YFAS 2.0 również istotnie negatywnie korelowały ze zdolnością do samokontroli (od -0,31 do -0,48) (patrz: tab. I).

Zgodnie z przyjętymi kryteriami diagnostycznymi YFAS 2.0 wyodrębniono cztery grupy badanych różniących się stopniem nasilenia objawów uzależnienia od jedzenia (zmienna niezależna): 0 bez objawów (85,61\% próby), 1 - w stopniu lekkim (1,16\%), 2 - umiarkowanym (2,32\%), i 3 - ciężkim $(10,9 \%)$. Za pomocą ANOVA zbadano istotność różnic między tymi grupami dla zmiennych zależnych: masy ciała, niekontrolowanego jedzenia (TFEQ-C), jedzenia emocjonalnego (TFEQ-E), ogólnego stopnia zaabsorbowania jedzeniem (SZJ) i jego wskaźników cząstkowych oraz dla zdolności do samokontroli. Wyniki tych analiz zawiera tabela II.

Stwierdzono, że masa ciała była istotnie, ale w niewielkim stopniu zależna od nasilenia objawów. Jedynie osoby $\mathrm{z}$ umiarkowanym nasileniem symptomów (grupa 2) istotnie różniły się wyższą 
persons without food addiction symptoms (group 0) in terms of higher average body mass.

The severity of symptoms of food addiction influenced more than 20\% of TFEQ-C and 25.5\% of TFEQ-E results variability. Individuals with severe (3) and moderate (2) symptoms of food addiction significantly differed in the higher intensity of difficulty in controlling their own eating from those without symptoms (0). In addition, people with severe (3) symptom intensity found it significantly more difficult to control their eating than people with mild (1) symptoms. Individuals with severe (3) and moderate (2) symptom intensity differed significantly to those without symptoms (0) in terms of emotional eating. Also, people with mild symptoms (1) had a higher predisposition to eat emotionally than those without symptoms (0) at a statistical significance tendency level (Table II).

A further ANOVA showed that the degrees of intensity of food addiction symptoms influenced $32.5 \%$ of the variability in the total SZJ score (involvement on food) and in the scores of the three components; almost $40 \%$ of the variability in "preoccupation and concentration on eating activities" (SZJ-1), over $20 \%$ of the variability in "craving and loss of control over eating" (SZJ-3) and $13.6 \%$ of the variability in "enhancing pleasure and improving mood" (SZJ-2). Those with severe (3) and moderate (2) intensity of food addiction symptoms significantly differed in their higher preoccupation with food and thus risk of addiction to those without symptoms (0) and those with mild intensity of symptoms (1). At the same time, the difference between the moderate symptom intensity group (2) and the mild symptom intensity group (1) was only at the statistical trend level. Moreover, those with severe symptom intensity (3) differed significantly in their risk of addictive eating from those with moderate intensity (2). Similar to the above and fully significant differences were found for the dependent variable "preoccupation and concentration on eating activities" (SZJ-1). However, regarding the dependent variable "enhancing pleasure and improving mood" (SZJ-2), subjects with severe symptom intensity (3) differed significantly in its higher intensity from both subjects without symptoms (0) and those with mild (1) and moderate symptom intensity (2). Moreover, a similar difference at the level of statistical tendency was also found between persons with moderate intensity of symptoms (2) and średnią masy ciała od osób bez objawów uzależnienia od jedzenia (grupa 0).

Stopnie natężenia symptomów uzależnienia od jedzenia wpływały na ponad $20 \%$ zmienności wyniku TFEQ-C i 25,5\% wyniku TFEQ-E. Osoby o ciężkim (3) i umiarkowanym (2) natężeniu objawów uzależnienia od jedzenia istotnie różniły się wyższym nasileniem trudności z kontrolą jedzenia od osób bez objawów (0). Ponadto osoby z ciężkim (3) natężeniem objawów różniły się istotnie większymi trudnościami kontroli jedzenia od osób z lekkim natężeniem objawów (1). Osoby o ciężkim (3) i umiarkowanym (2) natężeniu objawów różniły się istotnie wyższym nasileniem emocjonalnego jedzenia od osób bez objawów (0). Osoby o lekkim natężeniu objawów (1) miały również wyższą skłonność (istotność statystyczna na poziomie tendencji) do emocjonalnego jedzenia niż osoby bez objawów (0) (tab. II).

Kolejna ANOVA wykazała, że stopnie natężenia symptomów uzależnienia od jedzenia wpłynęły na $32,5 \%$ zmienności wyniku ogólnego SZJ (zaabsorbowania jedzeniem) oraz na wyniki trzech składowych; prawie 40\% zmienności w zakresie „Zaangażowania i koncentracji na jedzeniu” (SZJ-1), ponad 20\% w zakresie „przymusu jedzenia i utraty nad nim kontroli” (SZJ-3) oraz 13,6\% w zakresie „wykorzystywania jedzenia do sprawienia sobie przyjemności i poprawienia nastroju" (SZJ-2). Osoby o ciężkim (3) i umiarkowanym (2) natężeniu objawów uzależnienia od jedzenia istotnie różniły się wyższym zaabsorbowaniem jedzeniem i tym samym ryzykiem uzależnienia od osób bez objawów (0) oraz osób o lekkim natężeniu objawów (1), przy czym różnica między grupą o umiarkowanym natężeniu objawów (2) i grupą o lekkim natężeniu (1) była tylko na poziomie tendencji statystycznej. Co więcej, osoby z ciężkim natężeniem objawów (3) różniły się istotnie większym ryzykiem nałogowego jedzenia od osób z umiarkowanym natężeniem (2). Podobne do powyższych i w pełni istotne różnice stwierdzono w zakresie zmiennej zależnej „zaangażowanie i koncentracja na jedzeniu” (SZJ-1). Natomiast w zakresie zmiennej zależnej „wykorzystywania jedzenia do sprawienia sobie przyjemności i poprawienia nastroju" (SZJ-2) osoby o ciężkim natężeniu objawów (3) istotnie różniły się wyższym jej nasileniem zarówno od osób bez objawów (0), jak i tych o lekkim (1) i umiarkowanym ich natężeniu (2). Co więcej, podobna różnica na pozio- 


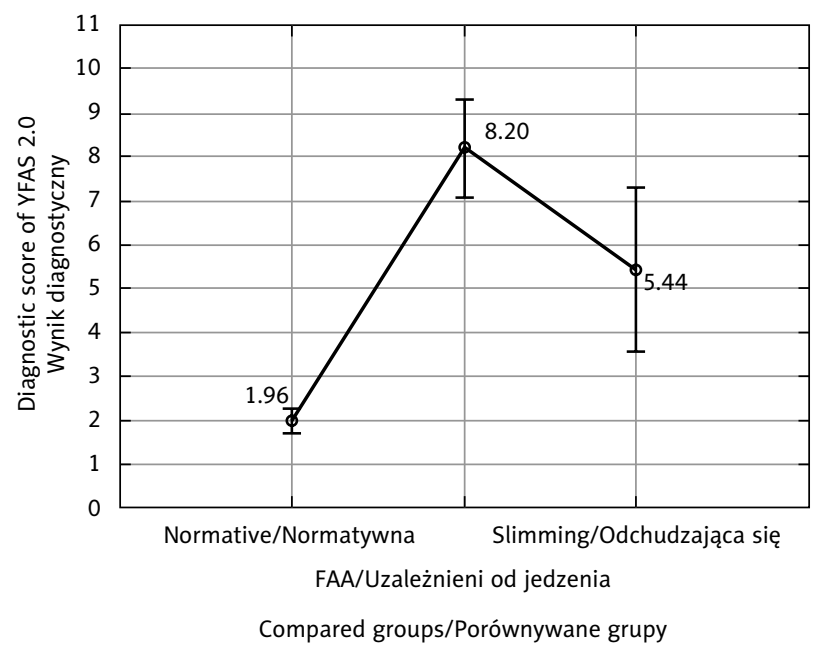

Vertical bars represent $0.95 \%$ confidence intervals/Pionowe słupki przedstawiają 0,95\% przedziały ufności

Figure 3. Comparison of the diagnostic results of YFAS 2.0 in the groups: normative vs. Food Addicts Anonymous vs. participants of the slimming programme

Rycina 3. Porównanie wyników diagnostycznych YFAS 2.0 w grupach: normatywnej vs. uzależnionych od jedzenia vs. uczestników programu odchudzania

persons with mild intensity of symptoms (1). In terms of the variable "craving and loss of control over eating" (SZJ-3), subjects with severe symptom intensity (3) differed significantly in its higher intensity from subjects without symptoms (0) and all lower degrees of symptom intensity ( 1 and 2 ). Those with moderate symptom intensity (2) also had significantly stronger food cravings and difficulty in controlling them than those without symptoms (0) (Table II).

The degrees of severity of food addiction symptoms explained almost $11 \%$ of the variability in self-control ability (SCS). It was found that those with severe (3) and mild symptom intensity (1) significantly differed from those without symptoms (0) in their lower self-control. Those with moderate symptom intensity (2) also had weaker self-control abilities than those without symptoms (0) - significance at the level of statistical trend (Table II).

At the end of the analyses aimed at confirming the validity of the Polish translation of the YFAS 2.0, the Kruskal-Wallis test was conducted to determine significant differences in diagnostic results between the three compared groups of respondents: normative $(n=397)$, food addicts anonymous (FAA) $(n=25)$ and participants in a weight-loss and fitness programme $(n=9)$. These groups were found to differ to a statistically significant degree in overall food addiction score $\mathrm{H}_{(2,431)}, p<0.001$ mie tendencji statystycznej wystąpiła też między osobami o umiarkowanym natężeniu objawów (2) i osobami o lekkim ich natężeniu (1). W zakresie zmiennej „przymus jedzenia i utrata nad nim kontroli” (SZJ-3) osoby o ciężkim natężeniu objawów (3) istotnie różniły się wyższym jej nasileniem od osób bez objawów (0) i wszystkich niższych stopni ich natężenia (1 i 2). Osoby o umiarkowanym natężeniu objawów (2) miały również istotnie silniejsze pragnienie jedzenia i trudności z jego kontrolowaniem niż osoby bez objawów (0) (tab. II).

Stopnie natężenia objawów uzależnienia od jedzenia wyjaśniały prawie $11 \%$ zmienności w zakresie zdolności do samokontroli (SCS). Stwierdzono, że osoby z ciężkim (3) i lekkim natężeniem objawów (1) istotnie różniły się od osób bez objawów (0) niższą samokontrolą. Osoby o umiarkowanym natężeniu objawów (2) miały również słabsze zdolności samokontroli niż osoby bez objawów (0) - istotność na poziomie tendencji statystycznej (tab. II).

Na zakończenie analiz mających potwierdzić trafność polskiego tłumaczenia YFAS 2.0 przeprowadzono test Kruskala-Wallisa istotności różnic $\mathrm{w}$ wynikach diagnostycznych $\mathrm{w}$ trzech porównywanych grupach badanych: normatywnej $(n=397)$, uzależnionych od jedzenia (FAA) $(n=25)$ oraz uczestników programu odchudzająco-kondycyjnego $(n=9)$. Stwierdzono, że grupy te istotnie statystycznie różnią się ogólnym wskaźnikiem uzależnienia od jedzenia $H_{(2,431)}$ 
(see Figure 3). FAAs had the highest mean YFAS 2.0 diagnostic score $(\mathrm{M}=8.20, \mathrm{SD}=3.62)$ significantly higher $(p<0.001)$ than the normative group $(\mathrm{M}=1.96, \mathrm{SD}=2.80)$. Individuals in the weightloss programme also had a significantly $(p=0.002)$ higher mean YFAS 2.0 diagnostic score $(\mathrm{M}=5.44$, $\mathrm{SD}=3.54)$ than those in the normative group. No significant differences in YFAS 2.0 diagnostic score were detected between the FAA and weight loss groups.

\section{- Discussion}

The aim of this study was a psychometric evaluation of the reliability and validity of the Polish version of YFAS 2.0 in the diagnosis of food addiction. The study was conducted in an opportunistic sample of ordinary people (i.e., normative sample) as well as on purposefully selected food addicts anonymous and participants of a weightloss programme. The distribution of YFAS 2.0 results in the sample was right-skewed, i.e., significantly more respondents did not show any symptoms of food addiction (42\%) and only 5.1\% confirmed them fully. This result is in line with expectations, since addictions, including food addiction, usually affect from a few to several percent of the general population [23, 46-48]. In the group of respondents confirming the symptoms of addiction, $10.9 \%$ could be classified as severely addicted to eating. Almost $80 \%$ of them were at least overweight, which is consistent with the results of other studies [47]. No differences between men and women were identified, which is a somewhat surprising result, as in most studies to date women more often had problems with eating addiction [23, 47].

YFAS 2.0 construct validity assessed with CFA has been fully confirmed. According to hypothesis 1, it has been shown that the Polish version of YFAS 2.0, like the original, measures 11 symptoms of food addiction [16]. The tested model obtained high fitting quality indicators. All factorial loads were statistically significant and high.

The reliability of YFAS 2.0 was assessed by means of several indicators: time stability of results in subscales, item-total correlation and internal consistency of a given subscale. High and very high results of these analyses were obtained (see Annex). Only the item-total correlation of item $28\left(r_{i t}=0.34\right)$, although within acceptable limits, $p<0,001$ (patrz: ryc. 3). FAA uzyskali najwyższy średni wynik diagnostyczny $(\mathrm{M}=8,20, \mathrm{SD}=3,62)$, istotnie wyższy $(p<0,001)$ niż grupa normatywna $(\mathrm{M}=1,96, \mathrm{SD}=2,80)$. Osoby z programu odchudzająco-kondycyjnego uzyskały również istotnie $(p=0,002)$ wyższy średni wynik diagnostyczny $(M=5,44, S D=3,54)$ niż osoby z grupy normatywnej. Między grupą FAA i odchudzającymi się nie stwierdzono istotnych różnic w wyniku diagnostycznym YFAS 2.0.

\section{- OMÓWIENIE}

Celem niniejszego badania była psychometryczna ocena rzetelności i trafności polskiej wersji YFAS $2.0 \mathrm{w}$ diagnozowaniu uzależnienia od jedzenia. Badania prowadzono na próbie przypadkowo zrekrutowanych osób (tj. próba normatywna) oraz celowo dobranych osób uzależnionych od jedzenia i uczestników programu odchudzania. Rozkład wyników YFAS $2.0 \mathrm{w}$ próbie był prawostronnie skośny, tzn. znacząco więcej badanych nie przejawiało jakichkolwiek objawów uzależnienia od jedzenia (42\%), a tylko $5,1 \%$ potwierdzało je w pełni. Wynik ten jest zgodny z oczekiwaniami, gdyż uzależnienia, w tym uzależnienia od jedzenia, dotyczą zazwyczaj od kilku do kilkunastu procent populacji ogólnej [23, 46-48]. W grupie badanych potwierdzających objawy $10,9 \%$ można było sklasyfikować jako uzależnionych od jedzenia w stopniu ciężkim. Prawie $80 \% \mathrm{z}$ nich miało co najmniej nadwagę, co jest zgodne $\mathrm{z}$ wynikami innych badań [47]. Nie stwierdzono różnic między kobietami a mężczyznami. Ten wynik nieco zaskakuje, gdyż w większości dotychczasowych badań kobiety miały częściej niż mężczyźni problemy $\mathrm{z}$ uzależnieniem od jedzenia [23, 47].

Trafność teoretyczna YFAS 2.0 oceniana za pomocą CFA została w pełni potwierdzona. Zgodnie $\mathrm{z}$ hipotezą 1 wykazano, że polska wersja YFAS 2.0, podobnie jak oryginał, mierzy 11 objawów uzależnienia od jedzenia [16]. Testowany model uzyskał wysokie wskaźniki jakości dopasowania. Wszystkie ładunki czynnikowe były statystycznie istotne i wysokie.

Rzetelność YFAS 2.0 oceniano za pomocą kilku wskaźników: stałości czasowej wyników w podskalach, mocy dyskryminacyjnej poszczególnych pozycji oraz spójności wewnętrznej danej podskali. Uzyskano wysokie i bardzo wysokie wyniki tych analiz (patrz Aneks). Jedynie moc dyskryminacyj- 
turned out to be the lowest. Removing this item from the questionnaire would significantly improve Cronbach's a of subscale 10 ("use in physically hazardous situations"), to which it belongs. This should be taken into account when developing the abbreviated version of YFAS 2.0, as Schulte and Gearhardt have done [18].

Other aspects of the validity of YFAS $\mathbf{2 . 0}$ have been assessed by testing a number of hypotheses, the verification of which will be discussed in turn.

The verification of hypotheses 2.1 and 2.2: YFAS 2.0 and body weight and BMI. A significant positive but weak relation between YFAS 2.0 results and body weight and BMI was demonstrated. There was a general, albeit poor regularity that the higher the degree of food addiction the higher the body weight and BMI. The degree of food addiction explained only $4 \%$ of the variability in body weight and BMI. A similar dependency was also shown in earlier studies. This result demonstrates the convergent validity of Polish version of YFAS 2.0. Although it has been systematically found that the severity of food addiction is significantly higher in obese groups than in those with normal body weight [47], many studies have not found a significant relationship between BMI level and YFAS result $[14,16]$. The lack of strong body weight and BMI relationships with YFAS 2.0 can be explained by the fact that some people with high level of food addiction engage in effective compensatory behaviours that reduce their weight [48]. Other factors may also be relevant, such as the duration of addiction.

In our study, about $11 \%$ of the sample met the criteria for severe food addiction. This group included the most overweight $(26.47 \%)$, obese (32.35\%) and clinically obese $(20.59 \%)$ people. For comparison, in Western studies, the prevalence of addiction ranged from $8.2 \%$ to $22.2 \%$ for the general population sample, and among obese people the criteria fulfil $25 \%$ to $42 \%$ studied persons $[14,24,49]$. It should be noted that the results obtained depend on the population from which the sample comes from, race, method of sample selection, age of participants (more common in middle-aged and older people), gender (more common in women), sexual orientation, socio-economic status (higher probability at lower status) and the presence of other disorders (e.g., bulimia) and health problems (e.g., obesi- na pozycji $28\left(r_{i t}=0,34\right)$, chociaż w granicach akceptowalności, okazała się najniższa. Usunięcie tej pozycji z kwestionariusza znacząco poprawiłoby a Cronbacha podskali 10. („używanie w sytuacjach fizycznie ryzykownych"), do której ona należy. Powinno to być uwzględnione przy opracowywaniu wersji skróconej YFAS 2.0, tak jak zrobili to Schulte i Gearhardt [18].

Inne aspekty trafności YFAS 2.0 oceniono, testując szereg hipotez, których weryfikacja zostanie po kolei omówiona.

Weryfikacja hipotez 2.1 i 2.2: YFAS 2.0 a masa ciała i BMI. Wykazano istotny pozytywny, ale słaby związek wyników YFAS $2.0 \mathrm{z}$ masą ciała i BMI. Zarysowała się ogólna, aczkolwiek słaba prawidłowość, że im wyższy stopień uzależnienia od jedzenia, tym większa masa ciała i BMI. Stopień uzależnienia od jedzenia wyjaśniał zaledwie 4\% zmienności w zakresie masy ciała i BMI. Podobne zależności wykazano także we wcześniejszych badaniach. Wynik ten przemawia za trafnością zbieżną polskiej wersji YFAS 2.0. Chociaż systematycznie stwierdzano, że nasilenie uzależnienia od jedzenia jest istotnie wyższe $\mathrm{w}$ grupach osób otyłych niż tych o prawidłowej masie ciała [47], to jednak $\mathrm{w}$ wielu badaniach nie stwierdzono istotnego związku między poziomem BMI a wynikiem YFAS $2.0[14,16]$. Brak silnych związków masy ciała i BMI $\mathrm{z}$ wynikiem YFAS 2.0 można tłumaczyć tym, że część osób $\mathrm{z}$ wysokim poziomem uzależnienia od jedzenia angażuje się w efektywne zachowania kompensacyjne, obniżające ich masę ciała [48]. Mogą tu też być istotne inne czynniki, np. czas trwania uzależnienia.

W naszych badaniach ok. $11 \%$ próby spełniało kryteria uzależnienia od jedzenia $\mathrm{w}$ stopniu ciężkim. W tej grupie znalazło się najwięcej osób z nadwagą $(26,47 \%)$, otyłych $(32,35 \%)$ i klinicznie otyłych (20,59\%). Dla porównania, w badaniach zachodnich rozpowszechnienie uzależnienia od jedzenia mieści się w przedziale od 8,2\% do 22,2\% dla próby populacji ogólnej, a wśród osób otyłych kryteria spełnia od $25 \%$ do $42 \%$ badanych $[14,24$, 49]. Należy zauważyć, że uzyskane wyniki zależą od populacji, z której pochodzi badana próba, rasy, sposobu doboru próby, wieku uczestników (częściej występuje u osób w wieku średnim i starszych), płci (częściej u kobiet), orientacji seksualnej, statusu społeczno-ekonomicznego (wyższe prawdopodobieństwo przy niższym statusie) oraz obecności innych zaburzeń (np. bulimii) i proble- 
ty). Hence, large discrepancies in the results obtained [23, 24].

Hypothesis 2.3: YFAS 2.0 and Scale of Involvement on Eating Behaviour (SZJ). As assumed, the overall result and the results in the subscales of the Polish version of YFAS 2.0 were significantly positive and highly correlated with the results of the SZJ. The overall result of YFAS 2.0 explains almost $50 \%$ of the SZJ score and from $26 \%$ to over $42 \%$ of its subscales. The higher the score in YFAS 2.0 the stronger "the craving and loss of control over eating" and "the preoccupation and concentration on eating activities" followed by "enhancing pleasure and improving mood". These results unambiguously confirm convergent validity of Polish version of YFAS 2.0.

Verification of hypothesis 2.4: YFAS $2.0 \mathrm{com}$ pared to TFEQ-13. It was found that the overall result and the YFAS 2.0 subscales correlated significantly positively and highly with uncontrolled eating and emotional eating. Each of these two key indicators of addictive eating, measured by TFEQ-13, explained approximately $30 \%$ of the variability in the overall YFAS 2.0 score. This means that the higher the scores in YFAS 2.0, the harder it is for the subjects to control their eating and that they gain pleasure and mood improvement from eating. The results suggest the convergent validity of this method. However, the strength of the relationship detected is lower than expected and that obtained by examining similar symptoms with SZJ (see above). It is possible that the obtained correlation coefficients would be stronger if the full, revised version of TFEQ-R18 in the Polish adaptation was used [50]. A limitation of TFEQ-13 application is that it was prepared for the study of adolescents [41]. Unfortunately, the Polish version of TFEQ-R18 was not yet available when our research on the Polish adaptation of YFAS 2.0 was underway.

Contrary to expectations, no significant correlation of YFAS 2.0 with the use of dietary restrictions, as measured by TFEQ-13, was found. A significant but very weak negative correlation of the cognitive restraint of eating was obtained only in relation to two subscale YFAS 2.0 in 1 "consumed more than planned" and 3 - "great deal of time spend eating". Accordingly, dietary restrictions account for just over $2 \%$ of the variability in mów zdrowotnych (np. otyłości). Stąd też duże rozbieżności w uzyskiwanych rezultatach $[23,24]$.

Weryfikacja hipotezy 2.3: YFAS 2.0 a Skala Zaabsorbowania Jedzeniem (SZJ). Tak jak zakładano, wynik ogólny oraz wyniki w podskalach polskiej wersji YFAS 2.0 istotnie pozytywnie i wysoko korelowały $\mathrm{z}$ wynikami SZJ. Wynik ogólny YFAS 2.0 wyjaśnia niemal 50\% wyniku SZJ oraz od $26 \%$ do ponad $42 \%$ jej podskal. Im wyższy wynik w YFAS 2.0, tym silniejsze w pierwszej kolejności „pożądanie, przymus jedzenia i utrata kontroli nad nim" oraz „zaabsorbowanie i koncentracja na czynności jedzenia”, a następnie ,jedzenie w celu dostarczenia sobie przyjemności i poprawy nastroju”. Wyniki te jednoznacznie potwierdzają trafność zbieżną polskiej wersji YFAS 2.0.

Weryfikacja hipotezy 2.4: YFAS 2.0 a TFEQ-13. Stwierdzono, że wynik ogólny oraz podskale YFAS 2.0 korelowały istotnie pozytywnie i wysoko $\mathrm{z}$ trudnościami $\mathrm{w}$ kontroli jedzenia oraz jedzeniem o podłożu emocjonalnym. Każdy z tych dwóch kluczowych wskaźników nałogowego jedzenia, mierzonych TFEQ-13, wyjaśniał po ok. 30\% zmienności wyniku ogólnego YFAS 2.0. Oznacza to, że im wyższe są wyniki badanych w YFAS 2.0, tym trudniej im kontrolować jedzenie oraz że cechuje ich wykorzystywanie jedzenia do sprawiania sobie przyjemności i poprawiania nastroju. Te rezultaty przemawiają za trafnością zbieżną walidowanej metody. Siła stwierdzonych zależności jest jednak mniejsza od oczekiwanej i tej, jaką uzyskano w badaniu podobnych symptomów za pomocą SZJ (patrz powyżej). Możliwe, że wskaźniki korelacji byłyby silniejsze, gdyby zastosowano pełną poprawioną wersję TFEQ-R18 w polskiej adaptacji [50]. TFEQ-13 został przygotowany do badania młodzieży i to ograniczało jego stosowanie [41]. Niestety polska wersja TFEQ-R18 nie była jeszcze dostępna, kiedy trwały nasze badania nad polską adaptacją YFAS 2.0.

Wbrew oczekiwaniom nie stwierdzono istotnych związków YFAS 2.0 ze stosowaniem restrykcji jedzeniowych mierzonych TFEQ-13. Istotną, ale bardzo słabą negatywną korelację stosowania restrykcji żywieniowych uzyskano tylko w odniesieniu do dwóch podskal YFAS 2.0, a mianowicie: 1 - „jedzenia więcej niż planowano”, oraz 3 - „spędzania dużej ilości czasu na jedzeniu". Stosowanie restrykcji żywieniowych odpowiada za nieco ponad $2 \%$ zmienności w zakresie tych dwóch objawów uzależnienia od jedzenia. Oznacza to, że stosowaniu restrykcji żywieniowych raczej nie 
these two symptoms of food addiction. This means that the use of nutritional restrictions is unlikely to be accompanied by overeating or spending a significant amount of time eating. This dependence seems obvious, as it is part of these restrictions. It has been found that, in general, the application of dietary restrictions does not significantly related to food addiction. This is most likely because there are two opposing trends here. On the one hand, addiction can coexist with limiting eating, using a diet or controlling eating, but it is difficult for addicts to maintain strict control, hence the negative value of these correlations (see Table I). On the other hand, the use of dietary restrictions can be, and is, a way of regaining control over eating and reducing body weight for eating addicts, or those with eating disorders in general, although it is often ineffective [51, 52]. This complex interdependence is most likely to manifest itself in the absence of significant correlations between these variables.

Hypothesis 3: YFAS 2.0 and self-control ability. As expected, a significant negative, high correlation between YFAS 2.0 and self-control was revealed. The higher YFAS 2.0 results, the lower the self-control. Deficits in self-control explain up to $25 \%$ of the variability in YFAS 2.0 , that is food addiction. This result confirms discriminant validity of Polish version of YFAS 2.0. It may come as a surprise why self-control deficits explain only $25 \%$ of YFAS 2.0 variability. It must be borne in mind that Self-Control Scale measures generalised rather than specific eating-related self-control difficulties [36]. People who are addicted to eating, or in any other way, generally have difficulty in controlling their lives and behaviours [37, 39, 53, 54].

Hypothesis 4 has been confirmed by the finding of significant differences in the selected indicators, depending on the diagnostic levels of food addiction (0 - no symptoms, 1 - mild, 2 - moderate, 3 - severe). It was shown that the diagnostic intensity degrees of food addiction significantly differentiated all the dependent variables considered. In general, people diagnosed as addicted to eating, especially those with severe degree, in comparison with those without symptoms, had higher body weight, were very occupied by and focused on eating, had a difficulty in controlling it, felt compulsion to eat, had an increased emotional eating, eat in order to make themselves comfortable and towarzyszy objadanie się czy poświęcanie znacznej ilości czasu na jedzenie. Zależność ta wydaje się oczywista, gdyż jest to element tych restrykcji. Stwierdzono, że ogólnie stosowanie restrykcji żywieniowych nie wiąże się istotnie $\mathrm{z}$ uzależnieniem od jedzenia. Jest tak prawdopodobnie dlatego, że występują tu dwie przeciwstawne tendencje. $\mathrm{Z}$ jednej strony uzależnienie może współwystępować $\mathrm{z}$ ograniczaniem jedzenia, stosowaniem diety czy kontrolowaniem jedzenia, przy czym osobom uzależnionym trudno jest utrzymać restrykcyjną kontrolę, stąd znak ujemny tych korelacji (patrz: tab. I). Z drugiej strony stosowanie restrykcji żywieniowych może być i jest dla osób uzależnionych od jedzenia, czy generalnie z zaburzeniami odżywiania, sposobem odzyskiwania kontroli nad jedzeniem i redukcji masy ciała, aczkolwiek często nieskutecznym [51, 52]. Złożona wzajemna zależność przejawia się prawdopodobnie w braku istotnych korelacji między tymi zmiennymi.

Weryfikacja hipotezy 3: YFAS 2.0 a zdolność do samokontroli. Zgodnie $\mathrm{z}$ oczekiwaniami stwierdzono istotną negatywną, wysoką korelację wyników YFAS 2.0 ze zdolnością do samokontroli. Im wyższe wyniki YFAS 2.0, tym mniejsza zdolność do samokontroli. Deficyty zdolności do samokontroli wyjaśniają do $25 \%$ zmienności wyniku YFAS 2.0, czyli uzależnienia od jedzenia. Wynik ten potwierdza trafność różnicową polskiej wersji YFAS 2.0. Tym niemniej może zaskakiwać, dlaczego tylko $25 \%$ zmienności YFAS 2.0 wyjaśniają deficyty samokontroli. Trzeba mieć na uwadze to, że SCS mierzy uogólnione, a nie specyficzne, związane z jedzeniem trudności samokontroli [36]. Osoby uzależnione od jedzenia, czy w jakikolwiek inny sposób, mają zasadniczo trudności ze sprawowaniem kontroli nad swoim życiem i zachowaniami $[37,39,53,54]$.

Hipoteza 4 została potwierdzona stwierdzeniem istotnych różnic w wybranych wskaźnikach zależnych od diagnostycznych stopni uzależnienia od jedzenia ( 0 - bez symptomów, 1 - w stopniu lekkim, 2 - w stopniu umiarkowanym, 3 - w stopniu ciężkim). Wykazano, że diagnostyczne stopnie nasilenia uzależnienia od jedzenia istotnie różnicowały wszystkie wzięte pod uwagę zmienne zależne. Osoby diagnozowane jako uzależnione od jedzenia, szczególnie w stopniu ciężkim, w porównaniu z osobami bez objawów uzależnienia miały większą masę ciała, były bardzo zaabsorbowane i skoncentrowane na jedzeniu, miały trudności $\mathrm{z}$ jego kontrolą, odczuwały przymus jedzenia, przejawiały na- 
to improve their mood. In addition, addicts had a markedly lower overall self-control capacity. These results demonstrate the diagnostic validity of Polish version of YFAS 2.0.

Hypothesis 5 has also been confirmed as food addicts anonymous score highest and significantly higher in YFAS 2.0 than people from the normative group. Also, individuals participating in the weight-loss programme obtain significantly higher scores than the normative sample participants (see Figure 3). These results unambiguously confirm diagnostic validity of Polish version of YFAS 2.0.

The results of all the above analyses confirm the validity of measuring the food addiction and its severity degrees with the Polish version of YFAS 2.0.

\section{Limitations}

The present study lacks an analysis of the relationship between the results of the Polish version of YFAS 2.0 and other disorders, especially eating disorders. Western studies using this tool have shown a significant relationship between eating addiction and binge overeating [26, 27], bulimia $[28,29]$, emotional regulation disorders and mood disorders [30]. It is particularly important to demonstrate a differentiation between food addiction and bulimia nervosa as well as binge-eating disorder, in which one of the leading symptoms is an impairment of food control $[3,4]$. Demonstrating specificity and differentiating food addiction from other disorders is one of the major research challenges [32].

Moreover, if the aim of the study was to characterise the problem of food addiction in the Polish population, future research would have to be conducted on an appropriately representative sample.

\section{- CONCLUSIONS}

Although food addiction is not an official category, either DSM-5 [3] nor ICD-11 [4], there are many reasons for identifying a disorder like this as a specific condition. Firstly, this stems from clinical practice and the self-reporting of those who identify the problem (http://www.foodaddictsanonymous.org/) [41, 55]. Secondly, there is a great convergence of the symptoms of food addiction with other addictive behaviours $[6,8,41$, silone jedzenie na tle emocjonalnym, jadły w celu sprawienia sobie przyjemności i poprawienia nastroju. Ponadto osoby uzależnione miały wyraźnie niższą ogólną zdolność do samokontroli. Wyniki te przemawiają za trafnością diagnostyczną YFAS 2.0.

Potwierdzono też hipotezę 5, że osoby uzależnione od jedzenia uzyskują najwyższe $\mathrm{i}$ istotnie wyższe wyniki w YFAS 2.0 niż osoby z próby normatywnej. Osoby uczestniczące $w$ programie odchudzania uzyskują również wyniki istotnie wyższe niż uczestnicy $\mathrm{z}$ próby normatywnej (patrz: ryc. 3). Rezultaty te jednoznacznie potwierdzają trafność diagnostyczną polskiej wersji YFAS 2.0.

Wyniki wszystkich powyższych analiz potwierdzają trafność pomiaru konstruktu uzależnienia od jedzenia i stopni jego nasilenia za pomocą polskiej wersji YFAS 2.0.

\section{Ograniczenia}

Ograniczeniem obecnych badań jest brak analizy związków wyników polskiej wersji YFAS 2.0 $\mathrm{z}$ innymi zaburzeniami, w tym szczególnie zaburzeniami odżywiania. $W$ zachodnich badaniach wykorzystujących to narzędzie wykazano istotny związek uzależnienia od jedzenia $\mathrm{z}$ napadowym objadaniem się [26, 27], bulimią [28, 29], zaburzeniami regulacji emocji i zaburzeniami nastroju [30]. Szczególnie istotne jest wykazanie odmienności uzależnienia od jedzenia z żarłocznością psychiczną i napadowym objadaniem się, w których jednym z wiodących objawów jest upośledzenie kontroli nad jedzeniem [3, 4]. Wykazanie specyfiki i odróżnienie uzależnienia od jedzenia od innych zaburzeń jest jednym z poważniejszych wyzwań badawczych [32].

Ponadto, jeśli celem badania miałoby być scharakteryzowanie problemu uzależnienia od jedzenia $\mathrm{w}$ polskiej populacji, to przyszłe badania musiałyby być przeprowadzone na odpowiednio reprezentatywnej próbie.

\section{- WNIOSKI}

Chociaż uzależnienie od jedzenie nie jest oficjalną kategorią DSM-5 [3] ani ICD-11 [4], to jednak istnieje wiele przesłanek przemawiających za wyodrębnianiem takiego zaburzenia. Po pierwsze, wynika to z praktyki klinicznej i relacji osób identyfikujących u siebie ten problem (http://www. foodaddictsanonymous.org/) $[41,55]$. Po drugie, stwierdza się ogromną zbieżność objawów uzależ- 
53]. The notion of addictive behaviours complements and is slowly replacing our traditional understanding of dependence $[41,53,54]$. Thirdly, there is increasing evidence that the psychological and cerebral mechanisms of food addiction are similar to other addictive behaviours (substantial and non-substantial) [1, 2, 10-13, 41, 54, 56]. The Polish version of YFAS 2.0 is a tool that displays very good psychometric parameters and provides opportunities to use it both for research on food addiction-related problems, and in clinical practice. nienia od jedzenia z innymi zachowaniami nałogowymi $[6,8,41,53]$. Pojęcie zachowań nałogowych uzupełnia i powoli wypiera tradycyjne rozumienie uzależnień $[41,53,54]$. Po trzecie, istnieje coraz więcej danych wskazujących na podobieństwo mechanizmów psychologicznych i mózgowych uzależnienia od jedzenia i innych zachowań nałogowych (substancjalnych i niesubstancjalnych) $[1,2,10-13,41,54,56]$. Polska wersja YFAS 2.0 jest narzędziem, które posiada bardzo dobre parametry psychometryczne i stwarza możliwości wykorzystania zarówno w badaniach problemu uzależnienia od jedzenia, jak i w praktyce klinicznej.

\section{Conflict of interest/Konflikt interesów}

None declared./Nie występuje.

Financial support/Finansowanie

None declared./Nie zadeklarowano.

\section{Ethics/Etyka}

The work described in this article has been carried out in accordance with the Code of Ethics of the World Medical Association (Declaration of Helsinki) on medical research involving human subjects, Uniform Requirements for manuscripts submitted to biomedical journals and the ethical principles defined in the Farmington Consensus of 1997.

Treści przedstawione w pracy są zgodne z zasadami Deklaracji Helsińskiej odnoszącymi się do badań z udziałem ludzi, ujednoliconymi wymaganiami dla czasopism biomedycznych oraz z zasadami etycznymi określonymi w Porozumieniu z Farmington w 1997 roku.

\section{References/Piśmiennictwo}

1. Davis C. Evolutionary and neuropsychological perspectives on addictive behaviors and addictive substances: relevance to the "food addiction" construct. Subst Abuse Rehabil 2014; 5: 129-37.

2. Schulte EM, Avena NM, Gearhardt AN. Which foods may be addictive? The roles of processing, fat content, and glycemic load. PLoS One 2015; 10(2): e 0117959.

3. American Psychiatric Association. Diagnostic and statistical manual of mental disorders - DSM-5. Washington: American Psychiatric Publishing; 2013.

4. World Health Organization. ICD-11 for mortality and morbidity statistics (ICD-11 MMS) 2018 version. https://icd.who.int/browse11/l-m/en (Accessed: 28.11.2019).

5. MacLean PS, Blundell JE, Mennella JA, Batterham RL. Biological control of appetite: a daunting complexity. Obesity 2017; 25: 8-16. DOI: 10.1002/oby.21771.

6. Granero R, Jiménez-Murcia S, Gearhardt AN, Agüera Z, Aymamí N, Gómez-Peña $\mathrm{M}$, et al. Validation of the Spanish version of the Yale Food Addiction Scale 2.0 (YFAS 2.0) and clinical correlates in a sample of eating disorder, gambling disorder, and healthy control participants. Front Psychiatry 2018; 9: 208. DOI: 10.3389/ fpsyt.2018.00208. 
7. Smith DG, Robbins TW. The neurobiological underpinnings of obesity and binge eating: a rationale for adopting the food addiction model. Biol Psychiatry 2013; 73(9): 804-10.

8. Fortuna JL. The obesity epidemic and food addiction: clinical similarities to drug dependence. J Psychoactive Drugs 2012; 44(1): 56-63.

9. Burrows T, Skinner J, McKenna R, Rollo M. Food addiction, binge eating disorder, and obesity: is there a relationship? Behav Sci 2017; 7(3): 54. DOI: 10.3390/bs7030054.

10. Hebebrand J, Albayrak Ö, Adan R, Antel J, Dieguez C, de Jong J, et al. "Eating addiction", rather than "food addiction", better captures addictive-like eating behavior. Neurosci Biobehav Rev 2014; 47: 295-306.

11. Burger KS. Frontostriatal and behavioral adaptations to daily sugar-sweetened beverage intake: a randomized controlled trial. Am J Clin Nutr 2017; 105(3): 555-63.

12. De Jong JW, Vanderschuren LJMJ, Adan RAH. Towards an animal model of food addiction. Obes Facts 2012; 5: 180-95.

13. Morin JP, Rodríguez-Durán LF, Guzmán-Ramos K, Perez-Cruz C, Ferreira G, Diaz-Cintra $\mathrm{S}$, et al. Palatable hyper-caloric foods impact on neuronal plasticity. Front Behav Neurosci 2017; 11: 19. DOI: 10.3389/fnbeh.2017.00019.

14. Gearhardt AN, Corbin WR, Brownell KD. Preliminary validation of the Yale Food Addiction Scale. Appetite 2009; 52(2): 430-6.

15. American Psychiatric Association. Diagnostic and statistical manual of mental disorders, 4 ed. Text Revision (DSM-IV-TR). Washington: American Psychiatric Publishing; 2000.

16. Gearhardt A, Corbin W, Brownell K. Development of the Yale Food Addiction Scale Version 2.0. Psychol Addict Behav 2016; 30: 113-21.

17. Meule A, Gearhardt AN. Ten Years of the Yale Food Addiction Scale: a Review of Version 2.0. Curr Addict Rep 2019; 6: 1-11.

18. Schulte EM, Gearhardt AN. Development of the modified Yale Food Addiction Scale version 2.0. Eur Eat Disord Rev 2017; 25(4): 302-8.

19. Khine MT, Ota A, Gearhardt AN, Fujisawa A, Morita M, Minagawa A, et al. Validation of the Japanese version of the Yale Food Addiction Scale 2.0 (J-YFAS 2.0). Nutrients 2019; 11(3): 687.

20. Brunault P, Courtois R, Gearhardt AN, Gaillard P, Journiac K, Cathelain S, et al. Validation of the French version of the DSM-5 Yale Food Addiction Scale in a nonclinical sample. Can J Psychiatry 2017; 62(3): 199-210.

21. Meule A, Müller A, Gearhardt AN, Blechert J. German version of the Yale Food Addiction Scale 2.0: prevalence and correlates of 'food addiction' in students and obese individuals. Appetite 2017; 115: 54-61.

22. Aloi M, Rania M, Muñoz RCR, Murcia SJ, Fernández-Aranda F, De Fazio P, et al. Validation of the Italian version of the Yale Food Addiction Scale 2.0 (I-YFAS 2.0) in a sample of undergraduate students. Eat Weight Disord 2017; 22(3): 527-33.

23. Pursey K, Stanwell P, Gearhardt A, Collins C, Burrows T. The prevalence of food addiction as assessed by the Yale Food Addiction Scale: a systematic review. Nutrients 2014; 6(10): 4552-90.

24. Penzenstadler L, Soares C, Karila L, Khazaal Y. Systematic review of food addiction as measured with the Yale Food Addiction Scale: implications for the food addiction construct. Current Neuropharmacology 2019; 17(6): 526-38.

25. Gearhardt AN, White MA, Masheb RM, Grilo CM. An examination of food addiction in a racially diverse sample of obese patients with binge eating disorder in primary care settings. Compr Psychiatry 2013; 54(5): 500-5.

26. Carter JC, Van Wijk M, Rowsell M. Symptoms of 'food addiction' in binge eating disorder using the Yale Food Addiction Scale version 2.0. Appetite 2019; 133: 362-9.

27. Hilker I, Sánchez I, Steward T, Jiménez-Murcia S, Granero R, Gearhardt AN, et al. Food addiction in bulimia nervosa: clinical correlates and association with response to a brief psychoeducational intervention. Eur Eat Disord Rev 2016; 24(6): 482-8.

28. de Vries SK, Meule A. Food addiction and bulimia nervosa: New data based on the Yale Food Addiction Scale 2.0. Eur Eat Disord Rev 2016; 24(6): 518-22. 
29. Sanlier N, Ağagündüz D, Toka O. Body Image, Food Addiction, Depression, and Body Mass Index in University Students. Ecol Food Nutr 2016; 55: 1-17.

30. Raymond KL, Lovell GP. Food addiction symptomology, impulsivity, mood, and body mass index in people with type two diabetes. Appetite 2015; 95: 383-9.

31. Stepaniak U, Micek A, Waśkiewicz A, Bielecki W, Drygas W, Janion M, et al. Prevalence of general and abdominal obesity and overweight among adults in Poland. Results of the WOBASZ II study (2013-2014) and comparison with the WOBASZ study (20032005). Polish Arch Intern Med 2016; 126(9): 662-71.

32. Bąk-Sosnowska M. Kryteria różnicowe zaburzenia z napadami objadania się i uzależnienia od pożywienia w kontekście przyczyn otyłości oraz jej leczenia. Psychiatr Pol 2017; 51(2): 247-59.

33. Rodríguez-Martín BC. Overeaters Anonymous: a mutual-help fellowship for food addiction recovery. Front Psychol 2018; 9: 1491. DOI: 10.3389/fpsyg.2018.01491.

34. Russell-Mayhew S, von Ranson KM, Masson PC. How does overeaters anonymous help its members? A qualitative analysis. Eur Eat Disord Rev 2010; 18: 33-42. DOI: 10.1002/ erv.966.

35. Hornowska E. Testy psychologiczne. Teoria i praktyka. Warszawa: Wydawnictwo Naukowe SCHOLAR; 2009.

36. Ogińska-Bulik N. Uzależnienie od czynności. Mit czy rzeczywistość? Warszawa: Difin; 2010.

37. Karlsson J, Persson L-O, Sjöström L, Sullivan M. Psychometric properties and factor structure of the Three-Factor Eating Questionnaire (TFEQ) in obese men and women. Results from the Swedish Obese Subjects (SOS) study. Int J Obes 2000; 24: 1715-25. DOI: $10.1038 /$ sj.ijo.0801442.

38. Tangney JP, Baumeister RF, Boone AL. High self-control predicts good adjustment, less pathology, better grades, and interpersonal success. J Pers 2004; 72: 271-324.

39. Hornowska E, Paluchowski J. Kulturowa adaptacja testów psychologicznych. In: Brzeziński J (ed.), Metodologia badań psychologicznych. Wybór tekstów. Warszawa: Wydawnictwo Naukowe PWN; 2004, p. 151-91.

40. Food and Addiction Science \& Treatment Lab. Development of YFAS 2.0 Scoring Thresholds. Department of Psychology, University of Michigan; 2019. https://fastlab.psych. lsa.umich.edu/yale-food-addiction-scale/ (Accessed: 28.11.2019).

41. Grzegorzewska I, Cierpiałkowska L. Uzależnienia behawioralne. Warszawa: Wydawnictwo Naukowe PWN; 2018.

42. Dzielska A, Mazur J, Małkowska-Szkutnik A, Kołoło H. Adaptacja polskiej wersji kwestionariusza Three-Factor Eating Questionnaire (TFEQ-13) wśród młodzieży szkolnej w badaniach populacyjnych. Problemy Higieny i Epidemiologii 2009; 90: 362-9.

43. Poprawa R. Polska adaptacja UPPS-P Skali Impulsywnego Zachowania oraz jej znaczenie w predykcji wybranych eksternalizowanych problemów i zaburzeń. Przegląd Psychologiczny 2016; 59: 95-116.

44. Bedyńska S, Książek M. Statystyczny drogowskaz 3. Praktyczny przewodnik wykorzystywania modeli regresji oraz równań strukturalnych. Warszawa: Wydawnictwo Akademickie Sedno; 2012.

45. Schreiber JB, Stage FK, King J, Nora A, Barlow EA. Reporting structural equation modeling and confirmatory factor analysis results: A review. J Educ Res 2006; 99: 323-37.

46. Kiejna A, Piotrowski P, Adamski T, Moskalewicz J, Wciórka J, Stokwiszewski J, et al. Rozpowszechnienie wybranych zaburzeń psychicznych w populacji dorosłych Polaków z odniesieniem do płci i struktury wieku - badania EZOP Polska. Psychiatr Pol 2015; 49(1): 15-27.

47. Pedram P, Wadden D, Amini P, Gulliver W, Randell E, Cahill F, et al. Food addiction: its prevalence and significant association with obesity in the general population. PLoS One 2013; 8(9): e 74832.

48. Meule A, Gearhardt AN. Five years of the Yale Food Addiction Scale: Taking stock and moving forward. Currt Addict Rep 2014; 1(3): 193-205.

49. Davis C, Curtis C, Levitan RD, Carter JC, Kaplan AS, Kennedy JL. Evidence that 'food addiction' is a valid phenotype of obesity. Appetite 2011; 57(3): 711-7. 
50. Brytek-Matera A, Rogoza R, Czepczor-Bernat K. The Three-Factor Eating Questionnaire-R18 Polish version: Factor structure analysis among normal weight and obese adult women. Arch Psychiatr Psychotherapy 2017; 3, 81-90.

51. Ogden J. Psychologia odżywiania się. Od zdrowych do zaburzonych zachowań żywieniowych. Kraków: WUJ; 2011.

52. Elran-Barak R, Sztainer M, Goldschmidt AB, Crow SJ, Peterson CB, Hill LL, et al. Dietary restriction behaviors and binge eating in anorexia nervosa, bulimia nervosa and binge eating disorder: Trans-diagnostic examination of the restraint model. Eat Behav 2015; 18: 192-6.

53. Billieux J, Khazaal Y, Maurage P, Heeren A. Are we overpathologizing everyday life? A tenable blueprint for behavioral addiction research. J Behav Addict 2015; 4(3): 119-23.

54. Ruddock HK, Dickson JM, Field M, Hardman CA. Eating to live or living to eat? Exploring the causal attributions of self-perceived food addiction. Appetite 2015; 95: 262-8.

55. Curtis C, Davis C. A qualitative study of binge eating and obesity from an addiction perspective. Eat Disord 2014; 22(1): 19-32.

56. De Ridder D, Manning P, Leong SL, Ross S, Sutherland W, Horwath C, et al. The brain, obesity and addiction: an EEG neuroimaging study. Sci Rep 2016; 6: 34-122. DOI: $10.1038 /$ srep34122. 


\section{Annex/Aneks}

Original and Polish version of the YFAS 2.0 - reliability indices and factor loads ( $\beta$ )

Oryginalna i polska wersja YFAS 2.0 - wskaźniki rzetelności i ładunki czynnikowe

\begin{tabular}{|c|c|c|c|c|c|}
\hline Subscales/Podskale & Items/Stwierdzenia & $r_{i t}$ & $\alpha$ & $r_{t r}$ & $\beta$ \\
\hline \multirow{3}{*}{$\begin{array}{l}\text { 1. Substance taken } \\
\text { in larger amount and } \\
\text { for longer period } \\
\text { than intended } \\
\text { Jedzenie więcej niż } \\
\text { planowano }\end{array}$} & $\begin{array}{l}\text { 1. When I started to eat certain foods, I ate much more than planned. } \\
\text { Kiedy zaczynałem jeść pewne pokarmy, zjadałem dużo więcej niż } \\
\text { zamierzałem. }\end{array}$ & 0.74 & \multirow{3}{*}{0.83} & \multirow{3}{*}{0.71} & \multirow{3}{*}{0.57} \\
\hline & $\begin{array}{l}\text { 2. I continued to eat certain foods even though I was no longer hungry. } \\
\text { Kontynuowałem jedzenie pewnych pokarmów, mimo że nie byłem } \\
\text { już głodny. }\end{array}$ & 0.74 & & & \\
\hline & $\begin{array}{l}\text { 3. I ate to the point where I felt physically ill. } \\
\text { Jadłem do momentu, aż poczułem się fizycznie chory. }\end{array}$ & 0.61 & & & \\
\hline \multirow{4}{*}{$\begin{array}{l}\text { 2. Persistent } \\
\text { desire or repeated } \\
\text { unsuccessful } \\
\text { attempts to quit } \\
\text { Niemożność } \\
\text { przerwania jedzenia }\end{array}$} & $\begin{array}{l}\text { 4. I worried a lot about cutting down on certain types of food, but I ate } \\
\text { them anyways. } \\
\text { Mimo że bardzo starałem się ograniczać spożywanie pewnego } \\
\text { rodzaju pokarmów, wciąż je jadłem. }\end{array}$ & 0.65 & \multirow{4}{*}{0.91} & \multirow{4}{*}{0.78} & \multirow{4}{*}{0.76} \\
\hline & $\begin{array}{l}25 . \text { I really wanted to cut down on or stop eating certain kinds of food, } \\
\text { but I just couldn't. } \\
\text { Naprawdę chciałem ograniczyć lub zaprzestać spożywania pewnych } \\
\text { pokarmów, ale nie potrafitem. }\end{array}$ & 0.81 & & & \\
\hline & $\begin{array}{l}\text { 31. I tried to cut down on or not eat certain kinds of food, but I wasn't } \\
\text { successful. } \\
\text { Próbowałem ograniczać bądź zaprzestać jedzenia pewnych rodzajów } \\
\text { żywności, ale nie udawało mi się to. }\end{array}$ & 0.86 & & & \\
\hline & $\begin{array}{l}\text { 32. I tried and failed to cut down on or stop eating certain foods. } \\
\text { Starałem się, ale nie dawałem rady ograniczyć lub zaprzestać } \\
\text { jedzenia pewnych pokarmów. }\end{array}$ & 0.85 & & & \\
\hline \multirow{3}{*}{$\begin{array}{l}\text { 3. Much time/activity } \\
\text { to obtain, use, } \\
\text { recover } \\
\text { Spędzanie dużej } \\
\text { ilości czasu na } \\
\text { jedzeniu }\end{array}$} & $\begin{array}{l}\text { 5. I spent a lot of time feeling sluggish or tired from overeating. } \\
\text { Czułem się osłabiony lub zmęczony z powodu przejedzenia. }\end{array}$ & 0.65 & \multirow[b]{3}{*}{0.81} & \multirow[b]{3}{*}{0.78} & \multirow[b]{3}{*}{0.69} \\
\hline & $\begin{array}{l}\text { 6. I spent a lot of time eating certain foods throughout the day. } \\
\text { Spędziłem dużo czasu na jedzeniu przez cały dzień. }\end{array}$ & 0.70 & & & \\
\hline & $\begin{array}{l}\text { 7. When certain foods were not available, I went out of my way to } \\
\text { get them. For example, I went to the store to get certain foods even } \\
\text { though I had other things to eat at home. } \\
\text { Kiedy pewne pokarmy były niedostępne, byłem w stanie zrobić } \\
\text { wiele, aby je uzyskać. Na przykład szedłem do sklepu, mimo że } \\
\text { miałem do wyboru inne produkty spożywcze w domu. }\end{array}$ & 0.63 & & & \\
\hline \multirow{4}{*}{$\begin{array}{l}\text { 4. Important social, } \\
\text { occupational, or } \\
\text { recreational activities } \\
\text { given up or reduced } \\
\text { Zaniedbanie } \\
\text { ważnych } \\
\text { aktywności }\end{array}$} & $\begin{array}{l}\text { 8. I ate certain foods so often or in such large amounts that I stopped } \\
\text { doing other important things. These things may have been working or } \\
\text { spending time with family or friends. } \\
\text { Spożywałem pewne pokarmy tak często lub w tak dużych ilościach, } \\
\text { że jadłem zamiast pracować lub spędzać czas ze znajomymi czy } \\
\text { rodziną. }\end{array}$ & 0.75 & \multirow{4}{*}{0.88} & \multirow{4}{*}{0.87} & \multirow{4}{*}{0.83} \\
\hline & $\begin{array}{l}\text { 10. I avoided work, school or social activities because I was afraid, } \\
\text { I would overeat there. } \\
\text { Unikałem pracy, szkoły lub aktywności towarzyskiej, ponieważ } \\
\text { obawiałem się, że mógłbym w tych sytuacjach objadać się. }\end{array}$ & 0.72 & & & \\
\hline & $\begin{array}{l}\text { 18. I felt so bad about overeating that I didn't do other important } \\
\text { things. These things may have been working or spending time with } \\
\text { family or friends. } \\
\text { Czułem się tak źle przez objadanie się, że nie mogłem zajmować się } \\
\text { ważnymi dla mnie rzeczami. }\end{array}$ & 0.76 & & & \\
\hline & $\begin{array}{l}\text { 20. I avoided work, school or social functions because I could not eat } \\
\text { certain foods there. } \\
\text { Unikałem pracy, szkoły lub wchodzenia w inne role społeczne, } \\
\text { ponieważ nie mógłbym w tych sytuacjach jeść pewnych pokarmów. }\end{array}$ & 0.79 & & & \\
\hline
\end{tabular}


Annex. Cont.

Aneks. Cd.

\begin{tabular}{|c|c|c|c|c|c|}
\hline Subscales/Podskale & Items/Stwierdzenia & $r_{i t}$ & $\alpha$ & $r_{t r}$ & $\beta$ \\
\hline \multirow{2}{*}{$\begin{array}{l}\text { 5. Use continues } \\
\text { despite knowledge } \\
\text { of adverse } \\
\text { consequences } \\
\text { Jedzenie pomimo } \\
\text { negatywnych } \\
\text { konsekwencji }\end{array}$} & $\begin{array}{l}\text { 22. I kept eating in the same way even though my eating caused } \\
\text { emotional problems. } \\
\text { Pozostawałem przy swoich nawykach żywieniowych, nawet jeśli } \\
\text { powodowały one problemy emocjonalne. }\end{array}$ & 0.78 & \multirow{2}{*}{0.88} & \multirow{2}{*}{0.83} & \multirow{2}{*}{0.84} \\
\hline & $\begin{array}{l}\text { 23. I kept eating in the same way even though my eating caused } \\
\text { physical problems. } \\
\text { Pozostawałem przy swoich nawykach żywieniowych, nawet jeśli } \\
\text { powodowały one dolegliwości fizyczne. }\end{array}$ & 0.78 & & & \\
\hline \multirow{2}{*}{$\begin{array}{l}\text { 6. Tolerance (marked } \\
\text { increase in amount; } \\
\text { marked decrease in } \\
\text { effect) } \\
\text { Tolerancja (wyraźny } \\
\text { wzrost ilości; } \\
\text { wyraźny spadek } \\
\text { efektów) }\end{array}$} & $\begin{array}{l}\text { 24. Eating the same amount of food did not give me as much } \\
\text { enjoyment as it used to. } \\
\text { Taka sama ilość jedzenia nie sprawiała mi tyle przyjemności co } \\
\text { wcześniej. }\end{array}$ & 0.72 & \multirow[b]{2}{*}{0.83} & \multirow[b]{2}{*}{0.79} & \multirow[b]{2}{*}{0.82} \\
\hline & $\begin{array}{l}\text { 26. I needed to eat more and more to get the feelings I wanted from } \\
\text { eating. This included reducing negative emotions like sadness or } \\
\text { increasing pleasure. } \\
\text { Potrzebowałem jeść coraz więcej, aby uzyskać pożądany przeze } \\
\text { mnie efekt, czyli redukcję negatywnych emocji, takich jak smutek lub } \\
\text { zwiększenie przyjemności. }\end{array}$ & 0.72 & & & \\
\hline \multirow{5}{*}{$\begin{array}{l}\text { 7. Characteristic } \\
\text { withdrawal } \\
\text { symptoms; } \\
\text { substance taken to } \\
\text { relieve withdrawal } \\
\text { Objawy odstawienne }\end{array}$} & $\begin{array}{l}\text { 11. When I cut down on or stopped eating certain foods, I felt irritable, } \\
\text { nervous or sad. } \\
\text { Kiedy ograniczałem lub zaprzestałem jedzenia pewnych pokarmów, } \\
\text { czułem się poirytowany, zdenerwowany lub smutny. }\end{array}$ & 0.82 & \multirow{5}{*}{0.91} & \multirow{5}{*}{0.78} & \multirow{5}{*}{0.79} \\
\hline & $\begin{array}{l}\text { 12. If I had physical symptoms because I hadn't eaten certain foods, } \\
\text { I would eat those foods to feel better. } \\
\text { Jeśli miałem fizyczne objawy spowodowane tym, że nie jadłem } \\
\text { pewnych pokarmów, to chciałem je zjeść, aby poczuć się lepiej. }\end{array}$ & 0.82 & & & \\
\hline & $\begin{array}{l}\text { 13. If I had emotional problems because I hadn't eaten certain foods, } \\
\text { I would eat those foods to feel better. } \\
\text { Jeśli miałem problemy emocjonalne, spowodowane tym, że nie } \\
\text { jadłem pewnych pokarmów, to chciałem je zjeść, aby poczuć się } \\
\text { lepiej. }\end{array}$ & 0.83 & & & \\
\hline & $\begin{array}{l}\text { 14. When I cut down on or stopped eating certain foods, I had physical } \\
\text { symptoms. For example, I had headaches or fatigue. } \\
\text { Kiedy ograniczałem lub zaprzestałem jedzenia pewnych pokarmów, } \\
\text { miałem dolegliwości fizyczne. }\end{array}$ & 0.63 & & & \\
\hline & $\begin{array}{l}\text { 15. When I cut down on or stopped eating certain foods, I had strong } \\
\text { cravings for them. } \\
\text { Kiedy ograniczałem lub zaprzestałem jedzenia pewnych pokarmów, } \\
\text { czułem silne pragnienie ich spożywania. }\end{array}$ & 0.74 & & & \\
\hline \multirow{3}{*}{$\begin{array}{l}\text { 8. Continued use } \\
\text { despite social } \\
\text { or interpersonal } \\
\text { problems } \\
\text { Jedzenie pomimo } \\
\text { problemów } \\
\text { w relacjach } \\
\text { z otoczeniem }\end{array}$} & $\begin{array}{l}\text { 9. I had problems with my family or friends because of how much } \\
\text { I overate. } \\
\text { Miewałem problemy z rodziną lub znajomymi z powodu objadania się. }\end{array}$ & 0.79 & \multirow{3}{*}{0.85} & \multirow{3}{*}{0.93} & \multirow{3}{*}{0.79} \\
\hline & $\begin{array}{l}\text { 21. I avoided social situations because people wouldn't approve } \\
\text { of how much I ate. } \\
\text { Unikałem spotkań towarzyskich, ponieważ ludzie mogliby nie } \\
\text { aprobować tego, ile zjadam. }\end{array}$ & 0.70 & & & \\
\hline & $\begin{array}{l}\text { 35. My friends or family were worried about how much I overate. } \\
\text { Moi znajomi lub rodzina martwili się tym, jak bardzo się objadałem. }\end{array}$ & 0.68 & & & \\
\hline \multirow{2}{*}{$\begin{array}{l}\text { 9. Failure to fulfil major } \\
\text { role obligation (e.g., } \\
\text { work, school, home) } \\
\text { Niepowodzenia } \\
\text { w wykonywaniu } \\
\text { obowiązków } \\
\text { (np. w pracy, szkole, } \\
\text { domu) }\end{array}$} & $\begin{array}{l}\text { 19. My overeating got in the way of me taking care of my family or } \\
\text { doing household chores. } \\
\text { Moje objadanie się przeszkadzało mi w zajmowaniu się moją } \\
\text { rodziną lub wykonywaniu obowiązków domowych. }\end{array}$ & 0.67 & \multirow{2}{*}{0.80} & \multirow{2}{*}{0.72} & \multirow{2}{*}{0.86} \\
\hline & $\begin{array}{l}\text { 27. I didn't do well at work or school because I was eating too much. } \\
\text { Nie szło mi dobrze w pracy lub szkole, ponieważ jadłem zbyt wiele. }\end{array}$ & 0.67 & & & \\
\hline
\end{tabular}


Annex. Cont.

Aneks. Cd.

\begin{tabular}{|c|c|c|c|c|c|}
\hline Subscales/Podskale & Items/Stwierdzenia & $r_{i t}$ & $\alpha$ & $r_{t r}$ & $\beta$ \\
\hline \multirow{3}{*}{$\begin{array}{l}\text { 10. Use in physically } \\
\text { hazardous situations } \\
\text { Stosowanie } \\
\text { w fizycznie } \\
\text { niebezpiecznych } \\
\text { sytuacjach }\end{array}$} & $\begin{array}{l}\text { 28. I kept eating certain foods even though I knew it was physically } \\
\text { dangerous. For example, I kept eating sweets even though I had } \\
\text { diabetes. Or I kept eating fatty foods despite having heart disease. } \\
\text { Kontynuowałem jedzenie pewnych pokarmów (słodkich lub } \\
\text { tłustych), chociaż zdawałem sobie sprawę, że jest to szkodliwe dla } \\
\text { mojego zdrowia. }\end{array}$ & 0.34 & \multirow{3}{*}{0.64} & \multirow{3}{*}{0.71} & \multirow{3}{*}{0.61} \\
\hline & $\begin{array}{l}\text { 33. I was so distracted by eating that I could have been hurt (e.g., } \\
\text { when driving a car, crossing the street, operating machinery). } \\
\text { Byłem tak rozkojarzony przez spożywanie jedzenia, że mógłbym ulec } \\
\text { wypadkowi (np. prowadząc samochód, przechodząc przez jezdnię, } \\
\text { obsługując urządzenie). }\end{array}$ & 0.57 & & & \\
\hline & $\begin{array}{l}\text { 34. I was so distracted by thinking about food that I could have } \\
\text { been hurt (e.g., when driving a car, crossing the street, operating } \\
\text { machinery). } \\
\text { Byłem tak rozkojarzony przez myślenie o jedzeniu, że mógłbym ulec } \\
\text { wypadkowi (np. prowadząc samochód, przechodząc przez jezdnię, } \\
\text { obsługując urządzenie). }\end{array}$ & 0.60 & & & \\
\hline \multirow{2}{*}{$\begin{array}{l}\text { 11. Craving, or } \\
\text { a strong desire or } \\
\text { urge to use } \\
\text { Głód/pożądanie }\end{array}$} & $\begin{array}{l}\text { 29. I had such strong urges to eat certain foods that I couldn't think } \\
\text { of anything else. } \\
\text { Miałem tak silne pragnienie spożycia pewnych pokarmów, że nie } \\
\text { mogłem skupić się na niczym innym. }\end{array}$ & 0.83 & \multirow{2}{*}{0.91} & \multirow{2}{*}{0.64} & \multirow{2}{*}{0.80} \\
\hline & $\begin{array}{l}\text { 30. I had such intense cravings for certain foods that I felt like I had to } \\
\text { eat them right away. } \\
\text { Miałem tak intensywne pragnienie zjedzenia pewnych pokarmów, że } \\
\text { musiałem zjeść je natychmiast. }\end{array}$ & 0.82 & & & \\
\hline \multirow[b]{2}{*}{$\begin{array}{l}\text { 12. Impairment or } \\
\text { distress } \\
\text { Cierpienie }\end{array}$} & $\begin{array}{l}\text { 16. My eating behavior caused me a lot of distress. } \\
\text { To w jaki sposób odżywiałem się było dla mnie powodem silnego } \\
\text { stresu. }\end{array}$ & 0.61 & \multirow[b]{2}{*}{0.76} & \multirow[b]{2}{*}{0.75} & \multirow[b]{2}{*}{-} \\
\hline & $\begin{array}{l}\text { 17. I had significant problems in my life because of food and eating. } \\
\text { These may have been problems with my daily routine, work, school, } \\
\text { friends, family, or health. } \\
\text { Miałem w życiu poważne problemy spowodowane jedzeniem. } \\
\text { Dotyczyły one takich sfer jak organizacja dnia, praca, szkoła, } \\
\text { znajomi, rodzina lub zdrowie. }\end{array}$ & 0.61 & & & \\
\hline Total/Ogółem & - & - & $0.94^{\circ}$ & $0.86^{\circ}$ & - \\
\hline \multicolumn{6}{|c|}{$\begin{array}{l}r_{i t} \text {-item-total correlation/moc dyskryminacyjna pozycji; } \alpha-\text { alpha Cronbacha } \\
r_{t r} \text { - test-retest correlation, all correlation coefficients significant with } p<0.001 / \text { korelacje test-retest, wszystkie wspótczynniki korelacji } \\
\text { istotne } z p<0,001 \\
\cdot-\text { total result of Cronbach's } \alpha \text { and total test-retest correlation }\left(r_{t}\right) \text { calculated without subscale 12/ogólny wynik } \alpha \text { Cronbacha oraz statości } \\
\text { czasowej }\left(r_{t}\right) \text { obliczony bez podskali } 12\end{array}$} \\
\hline
\end{tabular}


